University of Pennsylvania Carey Law School

Penn Law: Legal Scholarship Repository

Faculty Scholarship at Penn Law

Spring 2016

\title{
Occam's Phaser: Making Proportional Discovery (Finally) Work in Litigation by Requiring Phased Discovery
}

Michael Thomas Murphy

University of Pennsylvania Carey Law School

Follow this and additional works at: https://scholarship.law.upenn.edu/faculty_scholarship

Part of the Civil Procedure Commons, Courts Commons, Dispute Resolution and Arbitration Commons, and the Litigation Commons

\section{Repository Citation}

Murphy, Michael Thomas, "Occam's Phaser: Making Proportional Discovery (Finally) Work in Litigation by Requiring Phased Discovery" (2016). Faculty Scholarship at Penn Law. 2004.

https://scholarship.law.upenn.edu/faculty_scholarship/2004

This Article is brought to you for free and open access by Penn Law: Legal Scholarship Repository. It has been accepted for inclusion in Faculty Scholarship at Penn Law by an authorized administrator of Penn Law: Legal Scholarship Repository. For more information, please contact PennlawIR@law.upenn.edu. 


\title{
OCCAM's PHASER: MAKING PROPORTIONAL DISCOVERY (FINALLY) WORK IN LITIGATION BY REQUIRING PHASED DISCOVERY
}

\author{
Michael Thomas Murphy*
}

\begin{abstract}
This is an article about solving the problem of expensive electronic discovery in litigation by simply learning the most important facts first. Judges and parties often complain that the scope of information included in fact discovery in civil litigation is overinclusive and disproportionate to size of the dispute, resulting in overly expensive costs. The Federal Rules of Civil Procedure recently changed again to further emphasize the use of "proportional" limits in discovery, but provide little practical mechanism for parties, lawyers, and judges to make discovery "right-sized." This Article proposes that parties should be required to "phase" discovery by first setting the initial scope of discovery in a case as small as practicable and focused on the most important, outcome-determinative facts, and then following this small scope of discovery with additional "phases" if needed. The scope of discovery will then become incrementally broader in scope during each phase, but will only do so upon a showing of need for additional discovery. Phased discovery is used sporadically in litigation, often with success. This Article discusses these successes, considers potential drawbacks of phasing, and asks the key question: why wouldn't it work?
\end{abstract}

ABSTRACT. 89

INTRODUCTION

I. Proportional Discovery AND Why IT'S SO HARD to ACHIEVE ..................92

A. The Solution Is: Less Discovery. But How? .......................................94

B. Proportionality's Long Journey Around the Federal Rules ..................95

C. Proportionality in the 2015 Amendments: Is It Over, Did We Win? ....98

* Adjunct Professor, Drexel University Thomas R. Kline School of Law. Special thanks to Professor Dan Filler of the Kline School of Law and to John Pottow and Ted Becker of Michigan Law for their guidance and mentorship. Ian Mandell, Kline School of Law '05 and Elyse Cohen, Kline School of Law '05 provided invaluable research assistance. For Meg and for Louis Abrams. 
D. Why Hasn't Proportionality Caught On?

II. A Proposed PRoportionality SOlUtion: Mandatory PHASEd

DISCOVERY 106

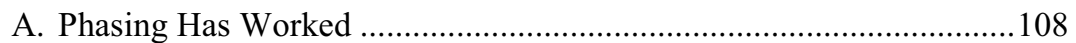

B. Phasing Fits Within the Rules ..........................................................113

III. WHAT COULD POSSIBLY GO WRONG? EXAMINING THE COUNTERARGUMENTS

A. "Phased Discovery Stretches Judicial Resources Too Thin" ..............116

B. "Phased Discovery Creates Discovery Without End" ..........................118

C. "Phased Discovery Will Take Too Long and Cost Too Much" ...........119

D. "A Dishonest Litigant Could Misuse Phased Discovery".....................121

E. "Phased Discovery Will Force a Single Witness to Endure Multiple Depositions" 122

F. "Phased Discovery Will Bring About Serial Summary Judgment

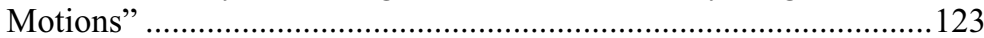

G. "Phased Discovery Is Only for Even-Footing 'Money' Cases”...........124 IV. But Would It Take?: The Practical Resistance to Phasing.................125

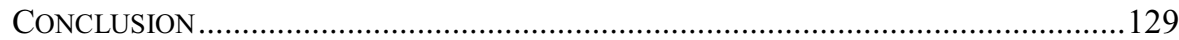




\section{INTRODUCTION}

It is clear that discovery in Federal Cases must become less expensive. ${ }^{1}$ But how? As electronically stored information (ESI) cost continues to dwarf litigation budgets, judges and clients are pushing lawyers to limit discovery. ${ }^{2}$ The recent reemphasis on proportional discovery in the 2015 amendments to the Federal Rules of Civil Procedure is the latest visible iteration of that push. ${ }^{3}$ But even those amendments only increase emphasis, which amounts to encouragement, not requirement. ${ }^{4}$ Parties are still free to set the limits of discovery as broad as they wish. ${ }^{5}$

This Article considers a more stringent approach to proportionality, in which the parties have to set limits to discovery. It examines the effectiveness of requiring discovery to be held in "phases," where the parties, with judicial oversight (and control if necessary) set the initial scope of discovery in a case to be proportionally as small as practicable, followed by any number of additional phases. The discovery "in play" in a case will then become incrementally broader in scope during each phase, but will only do so upon a showing of need, instead of a hurried and ill-informed analysis at the outset of the pleading phase of a case.

Part I is a recitation of the current law and past practice of "proportionality" with respect to the scope of discovery, as described in the Federal Rules, case law and scholarship. It examines in particular the struggle, and sometimes reluctance, of judges to set a scope of discovery in civil cases. It also describes the 2015 revisions to the Federal Rules of Civil Procedure, which place added emphasis on proportionality in discovery. It ends with a discussion of whether the revised rules go far enough toward achieving proportional discovery and suggests that the current system places too much of an onus on the parties' cooperating to make the scope of discovery "rightsized."

Part II suggests that Courts should anticipate conflict over the proportional scope of discovery and phase that discovery. In that way, discovery starts small, and grows only upon a showing that such growth is reasonable and necessary for the finding of truth. While this approach has its drawbacks and may not be appropriate for all circumstances, it is more likely than the current system to ensure that the discovery in each case is right-sized, preventing nuisance settlements and bloat. This Part cites cases and systems in which

1. See Gordon W. Netzorg \& Tobin D. Kern, Proportional Discovery: Making It the Norm, Rather than the Exception, 87 DENV. U. L. REV. 513, 513 (2010) (discussing the high costs of the current discovery system and declaring the system to be "broken").

2. See id. at 513-14.

3. Jay Tidmarsh, The Litigation Budget, 68 VAND. L. REV. 855, 855-57 (2015).

4. Id. at 875 .

5. Netzorg \& Kern, supra note 1, at 517 (discussing a tension between broad discovery and just, speedy resolution of disputes). 
phasing is used, to positive effect.

Part III examines the obstacles of implementing phased discovery, anticipating resistance to the idea of changing the discovery process and examining the strengths and weaknesses of such resistance.

The article briefly concludes in Part IV with a discussion of phased discovery's place in modern litigation, and whether it is a logical response to big data's disrupting litigation, drawing a parallel to computer-assisted review.

\section{Proportional Discovery ANd Why IT's So Hard To ACHIEVE}

Discovery in a lawsuit is, at its core, a mechanism by which parties and a factfinder collect and review information to determine what "really" happened. It is a quest for truth. ${ }^{6}$ Discovered information becomes admissible evidence to be used at a trial, where a factfinder weighs the litigants' competing assertions of truth. It is not a perfect system. ${ }^{7}$ It was never intended to be a perfect system. ${ }^{8}$ Even still, the system provides for a comprehensive collection, exchange, and examination of all relevant information as a means to locate and bring forth the truth. ${ }^{9}$ The default rule is that all such information should be collected, reviewed, and considered, no matter how ultimately important to the factual or legal determinations at issue. ${ }^{10}$

Often, "all of the relevant information" is a lot of information. It can be too much information. ${ }^{11}$ Simple math dictates that, under the American system, a party facing a $\$ 50,000$ potential judgment in a lawsuit but $\$ 100,000$ in legal

6. Robert G. Johnson, Discovery in Illinois and Federal Courts, 15 J. MARShall L. REV. 1, 1 (1982) (describing discovery as "an adversary proceeding in which is undertaken a 'search for truth."' (quoting People ex rel. Noren v. Dempsey, 139 N.E.2d 780, 783 (1957))).

7. See Netzorg \& Kern, supra note 1, at 515 (collecting sentiment and concluding that "[j]udges and litigants now routinely describe modern discovery as a 'morass,' 'nightmare,' 'quagmire,' 'monstrosity,' and 'fiasco.'” (footnote omitted) (twice quoting AM. CoLl. OF Trial Lawyers Task Force on Discovery \& InSt. FOR the AdVANCEMENT OF THE AM. Legal Sys., Interim Report on the Joint Project of the American College of Trial LAWYERS TASK Force on Discovery and the Institute fOR THE AdVANCEMENT OF THE AMERICAN LEgAL SYStem app. B at B-1 to B-2 (2008), http://www.actl.com/AM/TemplateRedirect.cfm?template=/cm/ContentDisplay.cfm\&Conten $\mathrm{tID}=3650$; then quoting PSEG Power N.Y., Inc. v. Alberici Constructors, Inc., No. 1:05-CV657 (DNH/RFT), 2007 WL 2687670, at*1, 8, 12 (N.D.N.Y. Sept. 7, 2007)).

8. Id. at 514 .

9. This is not the case in other countries. For example, one commentator noted that " $[t]$ he rest of the world rejects 'fishing expeditions' and tolerates decisions based on limited information in a way we do not." Richard L. Marcus, The Federal Rules of Civil Procedure Adapt to Discovery of Electronically Stored Information, in SHIRA SCHEINDLIN \& DANIEL CAPra, Electronic Discovery and Digital Evidence 22 (3d ed. 2015).

10. See Milberg LLP, Hausfeld LLP, E-Discovery Today: The Fault Lies Not in Our Rules . ., 4 FED. CTS. L. REV. 131, 139 (2011) (describing "open-deck" discovery).

11. See John H. Beisner, Discovering a Better Way: The Need for Effective Civil Litigation Reform, 60 DuKE L.J. 547, 573-77 (2010) (discussing the negative effects of excessive discovery costs). 
fees for discovery in that lawsuit has an easy, if morally questionable decision to make: the prudent move is to settle the suit for up to asking price regardless of the merits. ${ }^{12}$

This is no mere fantastic hypothetical. For example, e-discovery vendor DTI cites this case study:

[A] corporate client defending itself in a matter in which plaintiff's proposal for expanded discovery would actually have cost more than the entire amount at issue in the case! The original discovery request was for seven core custodians, ${ }^{13}$ requiring collection of $38 \mathrm{~GB}$ of data; of that, $1.4 \mathrm{~GB}$ (or less than 4\%) was determined to be relevant after searching the data with the latest technology, using client-supplied search terms. The cost of discovery for those seven custodians was a reasonable $\$ 10,000$, but in a motion to compel, the opposition requested an additional 65 custodians. Looking at actual processing and searching performed for the original custodians, reasonable per-unit cost estimate was established and, in response to the motion, the court was provided with an affidavit showing tiered costs: actual costs for the original seven custodians, and cost projections that included half (39 total) and all (72 total) of the additional custodians requested in the new motion. Based on the original "sample" of seven, discovery experts were able to project collection of all additional custodians at a cost of $\$ 153,000$, an amount clearly out of line with the $\$ 140,000$ at issue in the entire case. In light of the documented lack of proportionality between the discovery request and the value of the case, and given the low percentage of relevant data in the initial sample from the most promising custodians, the motion to expand scope made little sense and was dismissed. ${ }^{14}$

It is that "easy" decision that inspires commentators to declare the discovery system "broken," "flawed," and so forth. ${ }^{15}$ A 2008 survey by the

12. Id. at 573, citing Am. Coll. of Trial Lawyers \& InSt. For the AdVANCEMENT OF the Am. Legal Sys., InTERim Report on the JoInt Project of the AMERICAN College of TRIAL LAWYERS TASK FORCE ON DisCOVERY AND THE INSTITUTE FOR THE ADVANCEMENT OF THE AMERICAN LEgAL SYSTEM app. A at A-4 (2008), $\mathrm{http}: /$ www.actl.com/AM/TemplateRedirect.cfm?template=/cm/ContentDisplay.cfm\&Conten $\mathrm{tID}=3650$.

13. A "custodian" in this context is a person who has discoverable data in his or her possession or control.

14. Samantha Green, Proportionality. Are Discovery Costs Proportional to the Value and Importance of the Case?, ORAnge CTy. Attorney Journal (Apr. 4, 2015), $\mathrm{http}$ ://attorneyjournaloc.com/blog/2015/04/04/proportionality-are-discovery-costsproportional-to-the-value-and-importance-of-the-case/.

15. As it has been pointed out, though, that was the original intent of unlimited discovery. See Milberg LLP \& Hausfeld LLP, supra note 10, at 139 n.24 ("[T] he right of free and unlimited discovery before trial ... [will] probably result in the disposition of much litigation without the need of trial." (quoting Martin Conboy, Depositions, Discovery and Summary Judgments, 22 A.B.A. J. 881, 884 (1936)). This is unquestionably true today, but the modern view of this result is that it is a problem, not a solution. See Charles M. Yablon and Nick Landsman-Roos, Discovery About Discovery: Sampling Practice and the Resolution of Discovery Disputes in an Age of Ever-Increasing Information, 34 CARDOzo L. REV. 719, 721 (2012) (noting, among other examples, that "the [modern] controversial heightened pleading standard ... is expressly designed to protect certain defendants from 
Federal Judicial Center of lawyers in 3550 cases found that roughly a quarter of attorneys believed that the costs of discovery in their cases were "too high" relative to the amount in controversy, and roughly a third felt that discovery costs generally influence settlement. ${ }^{16}$ Roughly half of the attorneys surveyed knew of at least one client who settled a case primarily because of litigation costs, including discovery costs. ${ }^{17}$

\section{A. The Solution Is: Less Discovery. But How?}

"Fixing" the system falls on cost control. It is imperative to make discovery less expensive, so that that same $\$ 50,000$ judgment case costs less (hopefully far less) than $\$ 50,000$ to litigate. But how? Increases in document review technology can drive down costs and are a helpful development, if notably hesitantly adopted. ${ }^{18}$ But with the amount of information created by litigants (and everyone else) only increasing, litigants, judges, and scholars have put a greater emphasis on a fairly radical idea: just limit discovery to the important information.

This idea is "fairly radical" because it is in some sense at cross-purposes to the quest for truth. By limiting discovery, the actors in a lawsuit are consciously disregarding relevant information, which in many instances, given the imperfect nature of human recollection, no witness will remember. That information remains in the "unknown unknown," 19 and the limiters of

the 'burdens of discovery,' which are said to be 'sprawling, costly and hugely timeconsuming."' (first quoting Ashcroft v. Iqbal, 556 U.S. 662, 670 (2009); then quoting Bell Atl. Corp. v. Twombly, 550 U.S. 544, 560 n.6 (2007))).

16. Judge David G. Campbell, Memorandum to Judge Jefrrey Sutton Re: Proposed Amendments to the Federal Rules of Civil Procedure at Rules Appendix B6 (June 14, 2014), http://www.uscourts.gov/file/18218/download, [hereinafter June 2014 Rules Report].

17. Id; cf. Ann G. Fort, Rising Costs of E-Discovery Requirements Impacting Litigants, LAw.COM (Mar. 20, 2007), http:/www.nationallawjournal.com/id=900005554136/Rising-Costs-of-EDiscoveryRequirements-Impacting-Litigants?slreturn=20160317173351 (estimating a cost of $\$ 2.70$ to $\$ 4$ per email produced); Daniel C. Girard \& Todd I. Espinosa, Limiting Evasive Discovery: A Proposal for Three Cost-Saving Amendments to the Federal Rules, 87 DENV. U. L. Rev. 473, 474 n.4 (2010) ("Discovery should not be a sporting contest or a test of wills, particularly in a bankruptcy case where the parties' resources are limited and the dollar value of the stakes is often low[.] [The parties'] conduct in the discovery phase of this matter ha[s] significantly multiplied its burdens, both on the Trustee and the Court." (quoting In re Spoonemore, 370 B.R. 833, 844 (Bankr. D. Kan. 2007)) (second and third alterations in original)).

18. See Ralph C. Losey, Predictive Coding and the Proportionality Doctrine: A Marriage Made in Big Data, 26 Regent U. L. ReV. 7, 25 (2013-2014) (describing a slow adoption of predictive coding despite obvious benefits due to an initial lack of judicial approval).

19. This idea is commonly attributed to Donald Rumsfeld, who famously stated:

[T] here are known knowns; there are things we know we know. We also know there are known unknowns; that is to say we know there are some things we do not know. But there 
discovery are relying on their own imperfect knowledge and judgment to disregard information.

However, this "self-service" system of limitation has been languishing in the Rules of Civil Procedure as the best imperfect solution to discovery's proportionality problem. ${ }^{20}$ For many years before its 2015 amendment, Rule $26(\mathrm{~b})(2)(\mathrm{C})$ provided a system of proportionality that was restrictive, kicking in essentially when a litigant objected to the amount of discovery sought. ${ }^{21}$

Buttressing this concept was Rule 26(g)(1)(B)(iii), which requires a lawyer signing a discovery request (or response or objection) to certify that "to the best of [his or her] knowledge, information, and belief formed after a reasonable inquiry," the discovery demanded is "neither unreasonable nor unduly burdensome or expensive, considering the needs of the case, prior discovery in the case, the amount in controversy, and the importance of the issues at stake in the action." 22 Litigants have a responsibility to the system and themselves to agree to keep discovery affordable and proportional.

\section{B. Proportionality's Long Journey Around the Federal Rules}

That responsibility is not lost on rule-makers. The rules seem to prescribe proportional discovery, but it remains a legal mechanism that is, by many accounts, underutilized, with over half of federal judges ignoring the rule altogether and commentators calling the proportionality rule more of a "ripple" in the law than a sea change. ${ }^{23}$

are also unknown unknowns - the ones don't know we don't know.

Mark Steyn, Rummy Speaks the Truth, Not Gobbledygook, DAily TelegraPH, Dec. 9, 2003, http://www.telegraph.co.uk/comment/personal-view/3599959/Rummy-speaks-thetruth-not-gobbledygook.html. But it is also fairly common in project management circles. See Bonnie Biafore, Project Management Fundamentals, LyNDA.COM (Dec. 14, 2011), https://www.lynda.com/Business-Skills-tutorials/Project-Management-Fundamentals/807802.html.

20. See Netzorg \& Kern, supra note 1, at 517.

21. FeD. R. Civ. P. 26(b)(2)(C) (2014) (amended 2015).

22. FED R. CIV. P. 26(g)(1).

23. Jordan M. Singer, Proportionality's Cultural Foundation, 52 SANTA Clara L. ReV. 145, 180-81 (2012) (quoting 8 Charles Alan Wright, Arthur R. Miller \& Richard L. Marcus, Federal Practice and Procedure $§ 2008.1$ (3d ed. 2011)). Singer writes:

As one group of commentators noted, the "paucity of reported cases" citing to or applying the rule demands the conclusion that "the amendment itself seems to have created only a ripple in the caselaw." Other commentators have offered less charitable assessments, concluding that Rule 26(b)(2)(C) has been "ineffective," "seldom used," and "ignored" by the courts. Even federal judges, the most obvious beneficiaries of the 1983 proportionality provisions, have acknowledged that they very rarely invoke Rule $26(\mathrm{~b})(2)(\mathrm{C})$ on their own. Professor Miller himself lamented years later that the provisions have "all been largely ignored."

Id. (footnotes omitted) (first quoting The Judge's Role in Discovery, 3 REV. Litig. 89, 123 (1982) (comments of William F. Schwartzer); then quoting WRIGHT ET AL., supra, § 2008.1; then quoting Jessica DeBono, Comment, Preventing and Reducing Costs and Burdens Associated with E-Discovery: The 2006 Amendments to the Federal Rules of Civil 
Indeed, this lack of acceptance is likely the reason that commentators have noted a "peripatetic existence" of the proportionality rules, observing that they tend to breeze around the Federal Rules, moving to Rule 26(b)(2) in 1993, sharing time between Rule 26(b)(1) and Rule 26(b)(2) in 2000, then ending up (for the time being) in Rule 26(b)(2)(B) in 2006. ${ }^{24}$ Rule 26(b)(2) in its 1993 version sought to empower courts to limit discovery when necessary and stated that:

On motion or on its own, the court must limit the frequency or extent of discovery otherwise allowed by these rules or by local rule if it determines that: ... (iii) the burden or expense of the proposed discovery outweighs its likely benefit, considering the needs of the case, the amount in controversy, the parties' resources, the importance of the issues at stake in the action, and the importance of the discovery in resolving the issues. ${ }^{25}$

The 2000 Amendments added a "redundant" cross-reference to the limitations in Rule 26(b)(2) to the end of Rule 26(b)(1). ${ }^{26}$

Through this time, an emphasis on proportionality gained some ground. Some courts, such as the Seventh Circuit, have adopted proportionality considerations within their rules. ${ }^{27}$ In other instances, judges have developed

Procedure, 59 MERCER L. REv. 963, 969 (2008); then quoting Shira A. Scheindlin \& Jeffrey Rabkin, Electronic Discovery in Civil Litigation: Is Rule 34 Up to the Task?, 41 B.C. L. REV. 327, 349 (2000); then quoting Henry S. Noyes, Good Cause is Bad Medicine for the New EDiscovery Rules, 21 HARV. J. L. \& TECH. 49, 60-61 (2007); and then quoting Edward Becker et al., Transcript of the "Alumni" Panel on Discovery Reform, 39 B.C. L. REv. 809, 815 (1998)). Singer then cites data showing that "[n]early sixty percent of federal district and magistrate judges in a recent survey reported that they 'almost never' invoke Rule $26(\mathrm{~b})(2)(\mathrm{C})$ on their own initiative." Id. at $181 \mathrm{n} .116$ (quoting CORINA GERETY, TRIAL BENCH Views: Findings from a National Survey on Civil Procedure 31-32 (2010)). See also id. ("[T] judges"(quoting Ronald J. Hedges, Annotation, A View from the Bench and the Trenches: A Critical Appraisal of Some Proposed Amendments to the Federal Rules of Civil Procedure, 227 F.R.D. 123, 127 (2005))).

24. Tidmarsh, supra note 3, at 874-75; see also Elizabeth D. Laporte \& Jonathan M. Redgrave, A Practical Guide to Achieving Proportionality Under New Federal Rule of Civil Procedure 26, 9 FED. CTS. L. REV 20 (2015).

25. FED. R. Civ. P. 26(b)(2)(C) (1993) (amended 2000).

26. Jonah B. Gelbach \& Bruce H. Kobayashi, The Law and Economics of Proportionality in Discovery GA. L. REV. (forthcoming) (Univ. of Pa., Inst. for Law \& Econ. Research Paper No. 15-1; George Mason Law \& Econ. Research Paper No. 15-02, 2014), http://ssrn.com/abstract=2551520.

27. See Sean R Gallagher \& Lauren E. Schwartzreich, The Proportionality Test: Resolving E-Discovery Disputes in Employment Litigation (Midwinter Meeting of the Am. Bar Ass'n Employment Rights and Responsibilities Comm., 2010),

http://apps.americanbar.org/labor/errcomm/mw/Papers/2010/data/papers/005.pdf; see also Seventh Circuit Electronic Discovery Pilot Program, Proposed Standing Order Relating to the Discovery of Electronically Stored Information $\S 1.03$ (2009), http://www.ilcd.uscourts.gov/Statement\%20-\%20Phase\%20One.pdf (suggesting that parties use a proportionality analysis prospectively and that discovery requests "should be reasonably targeted, clear, and as specific as practical."); D. Md., Suggested Protocol for Discovery of Electronically Stored Information ("ESI") ๆ8(I),(K), 
this analysis into something more robust. In Rowe Entertainment, Inc. $v$. William Morris Agency, Inc., U.S. Magistrate Judge James C. Francis IV developed an eight-factor proportionality test for e-discovery considering:

(1) the specificity of the discovery requests; (2) the likelihood of discovering critical information; (3) the availability of such information from other sources; (4) the purposes for which the responding party maintains the requested data (5) the relative benefit to the parties of obtaining the information; (6) the total cost associated with production; (7) the relative ability of each party to control costs and its incentive to do so; and (8) the resources available to each party. ${ }^{28}$

What proportionality cases one can find tend to use the Rowe factors. ${ }^{29}$

Courts also have looked at slightly different factors, such as "(i) the number and complexity of the issues; (ii) the location, nature, number and availability of potentially relevant witnesses or documents; (iii) the extent of past working relationships between the attorney and the client, particularly in related or similar litigation; and (iv) the time available to conduct an investigation." 30 A "reasonable" search with respect to proportional discovery "is reasonable not on some idealized notion of adequacy, but 'reasonable under the circumstances." "31 However, there is no apparent authority in rules or case law giving adequate guidance on how to appropriately weight any of these factors. ${ }^{32}$

All of this examination does not add up to the widespread use of devices to limit discovery, however, as evidenced by a commentator's note that:

There thus exists a striking disconnect between the goal of proportionality embedded in the Federal Rules and the imbalanced reality of modern discovery. While not entirely a failure of the rules, this disconnect is

https://www.mdd.uscourts.gov/news/news/ESIProtocol.pdf (requiring, in working model for e-discovery, that Rule 26(f) conference discussions specifically include a proportionality analysis).

28. 205 F.R.D. 421, 429 (S.D.N.Y. 2002). For a full discussion of the Rowe decision, see Netzorg \& Kern, supra note 1, at 530.

29. Netzorg \& Kern, supra note 1, at 530; Zubulake v. UBS Warburg,

217 F.R.D. 309, 316 (S.D.N.Y. 2003) (Zubulake I) (explicitly adopting the Rowe test).

30. Steven C. Bennett, E-Discovery: Reasonable Search, Proportionality, Cooperation, and Advancing Technology, 30 J. Marshall J. Info. TeCH \& PrivaCy L. 433, 437-38 (2014) (quoting S2 Automation, LLC v. Micron Tech., Inc., No. CIV 11-0884 JB/WDS, 2012 U.S. Dist. LEXIS 120097, at*99-100 (D.N.M. Aug. 9, 2012)) (citing I-Med Pharma Inc. v. Biomatrix, Inc., Civ. No. 03-3677 (DRD), 2011 WL 6140658 (D.N.J. Dec. 9, 2011); St. Paul Reins. Co. v. Commercial Fin. Corp., 198 F.R.D. 508, 511 (N.D. Iowa 2000)).

31. Bennett, supra note 30, at 437 (quoting In re Delta/Airtran Baggage Fee Antitrust Litig., 846 F. Supp. 2d 1335, 1350 (N.D. Ga. 2012)).

32. Laporte \& Redgrave, supra note 24, at 44 ("The current Federal Rules (and associated Advisory Committee Notes) do not give specific direction to litigants and courts on how to properly consider the factors listed. Litigants and courts have factors, but no systematic approach for breathing life into those factors and ensuring that all applicable factors are considered. Accordingly, we lack the benefit of coherent and predictable case law."). 
attributable in part to the failure to address proportional discovery, a concept that is easy to articulate in general terms, yet can be difficult to implement in practice. $^{33}$

\section{Proportionality in the 2015 Amendments: Is It Over, Did We Win?}

Proportionality was once again on the move in 2015, switching back to Rule 26(b)(1) and a role of more prominence, establishing it as "a concept that is central to defining the appropriate scope of discovery." 34 Indeed, "[t]he committee suspected that the location of the proportionality standard, "buried among other discovery provisions, hindered its effectiveness." $" 35$

The new Rule 26(b)(1) states:

[A party] may obtain discovery regarding any nonprivileged matter that is relevant to any party's claim or defense and proportional to the needs of the case, considering the importance of the issues at stake in the action, the amount in controversy, the parties' relative access to relevant information, the parties' resources, the importance of the discovery in resolving the issues, and whether the burden or expense of the proposed discovery outweighs its likely benefit. $^{36}$

The draft Committee Note to Rule 26 explains that proportionality is the "collective responsibility" of the parties and the court. ${ }^{37}$

Commentators have noted that "the approach of moving the rule around, rather than changing its substance, suggests that, while the Advisory Committee understands that disproportionate discovery remains a problem for litigants and the courts, the Committee does not see an obvious alternative rule or amendment that would better address the problem."38

Further, it has been noticed that the rule itself is shifting from the reactive to the prospective. That is to say that proportionality generally comes up in litigation when a litigant oversteps his bounds and requests discovery clearly in excess of a reasonable scope, at which point his adversary objects, invoking the proportionality rules. ${ }^{39}$ Should the parties be unable to resolve this objection,

33. Id.

34. Christopher Benning \& Daniel Toal, Proportionality: Rarely Used, Primped for a Return?, N.Y. L.J., Dec. 2, 2014 ("By moving the proportionality rule out of Fed. R. Civ. P. 26(b)(2), 'Limitations on Frequency and Extent,' into 26(b)(1), which is entitled 'Scope in general,' the Advisory Committee seems to be signaling to parties and judges that the proportionality rule should no longer be seen solely as a limit on the scope of discovery. Indeed, the new location confirms that that the Advisory Committee instead views proportionality as a concept that is central to defining the appropriate scope of discovery.").

35. Gelbach and Kobayashi, supra note 26, at 4 (quoting The SEDOnA Conference Commentary on Proportionality in Electronic Discovery, The Sedona Conference WORKING Group SERIES 3 (Jan. 2013)).

36. FED. R. CIV. P. 26(b)(1).

37. Gelbach and Kobayashi, supra note 26, at 12.

38. Benning and Toal, supra note 34.

39. Dustin B. Benham, Proportionality, Pretrial Confidentiality, and Discovery 
the court will step in to resolve it. Thus a proportional scope is set out of conflict, not cooperation. The new rule would change that, encouraging parties and judges to take extra time and collaborate, to the extent practicable, at the outset of the case to set a reasonable scope for discovery. Commentators have noted that " $[t]$ hus, under the proposal, proportionality - first introduced in a less-prominent form in the 1983 amendments to Rule 26-would take center stage in setting the scope of discovery." 40

The purpose of the change is, as the Chief Justice wrote, to address the "most serious impediments to just, speedy, and efficient resolution of civil disputes." 41 The Committee Notes to the 2015 Amendments hope to rally support behind proportionality and deserve close examination. For example, they summarize proportionality's FRCP journey as follows:

Restoring proportionality as an express component of the scope of discovery warrants repetition of parts of the 1983 and 1993 Committee Notes that must not be lost from sight. The 1983 Committee Note explained that " $[t]$ he rule contemplates greater judicial involvement in the discovery process and thus acknowledges the reality that it cannot always operate on a self-regulating basis." The 1993 Committee Note further observed that "[ $[$ the information explosion of recent decades has greatly increased both the potential cost of wide-ranging discovery and the potential for discovery to be used as an instrument for delay or oppression." What seemed an explosion in 1993 has been exacerbated by the advent of e-discovery. The present amendment again reflects the need for continuing and close judicial involvement in the cases that do not yield readily to the ideal of effective party management. It is expected that discovery will be effectively managed by the parties in many cases. But there will be important occasions for judicial management, both when the parties are legitimately unable to resolve important differences and when the parties fall short of effective, cooperative management on their

Sharing, 71 WASH. \& LEE L. REV. 2181, 2223 (2014). Benham writes:

Currently, attorneys are expected to exercise discretion to frame discovery requests within the scope allowed by Rule 26(b)(1), and if they fail to do so, opposing counsel can request limitations, or protections, from the court. Likewise, current rule $26(\mathrm{~g})$ mandates that attorneys who sign discovery requests certify that the requests are, among other things, proportional. If necessary, the court then exercises its discretion to refine discovery along those same lines.

The amendments, however, would emphasize attorneys' obligation to consider what is proportional when they exercise their discretion to frame discovery requests in the first place. Id. (footnotes omitted).

40. Id. at 2222 (footnote omitted).

41. The 2015 discovery amendments were, unusually, front and center in Chief Justice Roberts's 2015 Year-End Report. John G. Roberts, Jr., 2015 YEAR-END REPORT ON THE FEDERAL JUDICIARY 4 (Dec. 31, 2015) [hereinafter ROBERTS 2015 REPORT], http://www.supremecourt.gov/publicinfo/year-end/2015year-endreport.pdf ("Many rules amendments are modest and technical, even persnickety, but the 2015 amendments to the Federal Rules of Civil Procedure are different. Those amendments are the product of five years of intense study, debate, and drafting to address the most serious impediments to just, speedy, and efficient resolution of civil disputes."). The Chief Justice's echoing of the language of Rule 1 is no accident. See FED. R. CIV. P. 1. 
own. $^{42}$

There's an inherent rhetorical tension in this long passage between selfregulating proportionality from the parties, and judicial involvement. If you break down the Committee's message into simple bullet points, it reads like this:

- $\quad$ Like we said before

- There will have to be close judicial involvement

- Because parties cannot always keep discovery proportional

- Especially now that we have to deal with Big Data.

- So there needs to be close judicial involvement

- In those cases where parties cannot always keep discovery proportional

- But parties can sometimes keep discovery proportional

- Though sometimes they cannot keep discovery proportional

- In which case there needs to be close judicial involvement

- For those cases where the parties cannot keep discovery proportional.

The analysis above cannot be much more reductionist when one puts it this way, but it is now easy to see the tension. Where does party autonomy stop, and judicial intervention begin? It reads as if the drafters want to call for increased judicial intervention, but do not want to have to call for such intervention. That is to say it would be better for everyone if the intervention were not needed, as judges are already overworked and cooperation between counsel should be the norm. However, as the data have shown, lawyers are simply not happy with the amount of discovery and their own ability to cooperate as both adversaries and partners in dispute resolution. ${ }^{43}$ If lawyers banded together and mutually agreed to reduce proportionality at the cost of the occasional advantage in individual litigations, that may create a sea change. But that system only works

42. FED. R. CIV. P. 26 advisory committee's notes to 2015 amendment (alteration in original) (discussing the impact of the "information explosion" on the 1993 changes to Rule 26).

43. June 2014 Rules Report at B-6 to B-7.

Surveys of ABA Section of Litigation and NELA attorneys found more than $80 \%$ agreement that discovery costs are disproportionately high in small cases, with more than $40 \%$ of respondents saying they are disproportionate in large cases. In the survey of the ABA Section of Litigation, $78 \%$ percent [sic] of plaintiffs' attorneys, $91 \%$ of defense attorneys, and $94 \%$ of mixed-practice attorneys agreed that litigation costs are not proportional to the value of small cases, with $33 \%$ of plaintiffs' lawyers, $44 \%$ of defense lawyers, and $41 \%$ of mixedpractice lawyers agreeing that litigation costs are not proportional in large cases. In the NELA survey, which included primarily plaintiffs' lawyers, more than $80 \%$ said that litigation costs are not proportional to the value of small cases, with a fairly even split on whether they are proportional to the value of large cases. An IAALS survey of corporate counsel found $90 \%$ agreement with the proposition that discovery costs in federal court are not generally proportional to the needs of the case, and $80 \%$ disagreement with the suggestion that outcomes are driven more by the merits than by costs. In its report summarizing the results of some of the Duke empirical research, IAALS noted that between $61 \%$ and $76 \%$ of the respondents in the ABA, ACTL, and NELA surveys agreed that judges do not enforce the rules' existing proportionality limitations on their own. 
as well as its worst actor, and research (as well as a 30-year history of proportionality struggles) suggests that a self-regulating system is unlikely to be effective. ${ }^{44}$

Even the drafters grudgingly admit that, as time goes by, proportionality in discovery increasingly requires judicial intervention. One can see such an admission in a memorandum by the Chair of the Advisory Committee on the Federal Rules of Civil Procedure stating that one of the goals of the 2015 amendments is that:

Case management will begin earlier, judges will be encouraged to communicate directly with the parties, relevant topics are emphasized for the initial case management conference, early Rule 34 requests will facilitate a more informed discussion of necessary discovery, proportionality will be considered by all participants, unnecessary discovery motions will be discouraged, and obstructive Rule 34 responses will be eliminated. ${ }^{45}$

That sounds like a win-win-win, but it is important to note that nothing in the Federal Rules prevents parties (or judges) from doing just that in 2012 or 2014, making the rule change not altogether "new." And, it has been noted that "attention to the proportionality provisions has grown since 1994, and endorsement of their use has widened." ${ }^{46}$ However, as the rule change shows, courts and attorneys (and especially, clients) have not seen the widespread use of proportionality that such attention and endorsement should engender.

\section{Why Hasn't Proportionality Caught On?}

That is to say, if proportionality is so important and so useful, why is it still considered a "growing" trend and not a ubiquitous part of discovery? ${ }^{47}$ Why don't judges take the more active role contemplated by (and now almost required by) the rules? Scholarship shows no shortage of thoughtful reasons.

44. Id. at B-6, stating:

Other surveys prepared for the Duke Conference showed greater dissatisfaction with the costs of civil discovery. In surveys of lawyers from the American College of Trial Lawyers (ACTL), the ABA Section of Litigation, and NELA, more lawyers agreed than disagreed with the proposition that judges do not enforce Rule 26(b)(2)(C) to limit discovery. The ACTL Task Force on Discovery and IAALS reported on a survey of ACTL fellows, who generally tend to be more experienced trial lawyers than those in other groups. A primary conclusion from the survey was that today's civil litigation system takes too long and costs too much, resulting in some deserving cases not being filed and others being settled to avoid the costs of litigation. Almost half of the ACTL respondents believed that discovery is abused in almost every case, with responses being essentially the same for both plaintiff and defense lawyers.

45. Id. at B-14.

46. 4 Charles Alan Wright \& Arthur R. Miller, Federal Practice and Procedure: Civil $\S 2008.1$ at 158 (3d ed. 2010).

47. Gelbach \& Kobayashi, supra note 26, at 4 ("The focus on organizational changes in the 2014 Amendments suggests the committee continues to assume that the apparent shortfall in judges' and parties' use of the proportionality standard results partly from a lack of awareness of the proportionality standards' applicability to their case."). 
A key problem may be that the factors in the proportionality rules are not weighted, making for a difficult test. ${ }^{48}$ Another problem could be that a natural tendency exists to use the amount in controversy as the dominant factor to determine proportionality. We are, after all, examining cost. ${ }^{49}$ That tendency is likely to be helpful in cases such as a commercial dispute among litigants on equal financial footing, but troublesome in cases involving significant nonmonetary rights such as actions to enforce constitutional or statutory rights. ${ }^{50}$ This is likely why "the importance of the issues at stake in the action" is moving to the front of the new rule and "the amount in controversy" is moving back.

The most recurrent problems, however, come from three sources. First, proportionality of discovery, or its proper scope, must be set early on in a case, when facts are generally not well-known nor arguments well-developed. This tension can be somewhat described thusly:

It is widely acknowledged that the proportionality rule is difficult to apply, particularly at the early stages of discovery. Perhaps the most widely acknowledged problem with the [proportionality] rule is that it requires judges to make, at a very early stage, estimations about the merits of a case, which judges are characteristically reluctant to do. ${ }^{51}$

48. Tidmarsh, supra note 3, at 875-76 ("In deciding whether 'the burden or expense of the proposed discovery outweighs its likely benefit,' a court considers 'the needs of the case, the amount in controversy, the parties' resources, the importance of the issues at stake in the action, and the importance of the discovery in resolving the issues.' No particular weight is given to any factor. Such open-ended, multi-factor tests breed uncertainty and are subject to manipulation." (footnote omitted)).

49. Indeed, a practice note from the law firm Jones Day belies this tendency. In discussing the adoption of the 2015 FRCP Amendments, the drafters write that "simply noting that the amount in controversy is large and the responding party's resources are substantial is not a sufficient proportionality analysis. Rather, the benefit of the information requested should be weighed against the costs. Conversely, a hefty price tag does not alone indicate 'disproportionality.' All proportionality factors must be considered." Laura E. Ellsworth et al., Significant Changes to the Federal Rules of Civil Procedure Expected to Take Effect December 1, 2015: Practical Implications and What Litigators Need to Know, JONES DAY (September 2015), http://www.jonesday.com/significant-changes-to-the-federalrules-of-civil-procedure-expected-to-take-effect-december-1-12015-practical-implicationsand-what-litigators-need-to-know-09-25-2015.

50. See, e.g., Kleen Prods. LLC v. Packaging Corp. of Am., No. 10 C 5711, 2012 WL 4498465, at*11 (N.D. Ill. Sept. 28, 2012); John B. v. Goetz, 879 F. Supp. 2d 787, 887 (M.D. Tenn. 2010) ("Yet, with repeated judicial findings of the Defendants' violations of children's rights to medical care under federal law, any cost of ESI discovery is far outweighed by the benefits of the improved health of the children in this state."]

51. Benning \& Toal, supra note 34 (footnote omitted). The authors continue:

This challenge leads to few written decisions on proportionality grounds. In fact, the lack of case law on the topic to assist judges in making these difficult judgments is among the factors that perpetuate the lack of case law on the topic: Judges are even less inclined to make these difficult and precarious determinations when they do not have case law on which to base their decisions.

Id. This is so; case law on proportionality in discovery is relatively scarce. 
This statement presupposes that the proportionality of discovery is itself an estimation of the merits of a case. It's not, but one-shot discovery, with little recourse on appeal, can make it seem that way. ${ }^{52}$

Second, parties tend not to agree on the proper proportions of discovery, particularly when those proportions are tied to the "dollar value" of the claims, which is often the key (sometimes only) metric in play. ${ }^{53}$ So the common perception that the system can adopt proportionality by "requir[ing] either by protocol or local rule that there be a discussion of proportionality before the discovery plan required by Rule26(f) is submitted to the court" ${ }^{, 5}$ is troublesome. For judges and longtime practitioners can - and do-say that it is one thing to require litigants to discuss something, and another thing entirely to convince them to work together in good faith to reduce the scope of a lawsuit. ${ }^{55}$ That is to say that the 2015 amendments only increase emphasis on proportionality, instead of requiring it. Parties are still free to set the limits of discovery as broadly as they wish.

It is a practice that is in some ways, to some practitioners, antithetical to the concept of zealous advocacy, and also a practice that, in the short term and for the short-sighted, takes money away from a lawyer's accounts receivable. ${ }^{56}$

52. Dan H. Willoughby Jr., Rose Hunter Jones \& Gregory R. Antine, Sanctions for EDiscovery Violations: By the Numbers, 60 DUKE L.J. 789, 797-98 (2010) (“Appellate review of e-discovery sanction cases has been limited, perhaps because many cases settle or are otherwise not appealed."). Also, a major law firm's yearly e-discovery update noted "infrequent instances where e-discovery was addressed squarely by a circuit court of appeals.” 2011 Mid-Year E-Discovery Update, GIBSON DunN (July 22, 2011), http://www.gibsondunn.com/publications/pages/2011Mid-YearE-DiscoveryUpdate.pdf.

53. Ralph C. Losey, Lawyers Behaving Badly: Understanding Unprofessional Conduct in E-Discovery, 60 MERCER L. REV. 983, 997-98 (2009) ("Parties in litigation, especially at the commencement of a case when discovery plans are formed, rarely agree on the value of a case. This disagreement produces disputes regarding what effort is fair and reasonable under the circumstances.").

54. John L. Carroll, Proportionality in Discovery: A Cautionary Tale, 32 CAMPBELL L. REV. 455, 462 (2010).

55. Liesa L. Richter, Making Horses Drink: Conceptual Change Theory and Federal Rule of Evidence 502, 81 FORDHAM L. REV. 1669, 1678 (2013); Netzorg \& Kern, supra note 1 , at 528 ("Attorneys are required to zealously advocate for their clients. Excessive or evasive discovery tactics are among the most commonly used tools to induce a favorable settlement-or to deter a claim altogether, depending on which side abuses the process. Unless and until attorneys are forced to make discovery proportionate, the abuses outlined in this article will continue. Guidelines, to put it bluntly, are not enough."); Michael J. Hanrahan, Game-Changing Federal "Proportionality" Discovery Rule Effective December 1, 2015, Fox, O’Neill, Shannon, S.C. (Oct. 21, 2015), http://www.foslaw.com/newsviews/game-changing-federal-proportionality-discovery-rule-effective-december-1-2015 ("Unending discovery becomes a settlement tactic, not an investigational tool.").

56. The idea that smaller discovery scope equals less money for lawyers is generally not accurate. In the long term, an efficient lawyer will grow his client base through a reputation for bringing cases to resolution quickly and under budget. But the idea, however misguided, persists, and therefore judges and rule makers must account for it. See Patrick Oot et al., Mandating Reasonableness in a Reasonable Inquiry, 87 DENV. U. L. Rev 533, 
Rules, judges, and practitioners all stress, as is just and proper, open and honest cooperation between parties in setting the scope of discovery and the best means of avoiding injustice. ${ }^{57}$ But when the law is practiced by people-not just people, but lawyer people - of varying degrees of reasonableness, such open and honest cooperation is not ubiquitous. ${ }^{58}$ Put another way, the system of setting proportional discovery must anticipate the uncooperative and the conflict-driven.

Third, and perhaps foremost, the current discovery system of setproportionality-and-go is an all-or-nothing proposition. ${ }^{59}$ That is to say, the scope of discovery is set, along with a deadline, at the beginning of a case, often at the Rule 16 conference. The judge sends the parties off with an order in hand, and, with the weariness of a parent handing the car keys to a teenager, an admonishment to try to solve disputes amicably this time. Discovery then proceeds along that scope, and adhering to that deadline, expanding scope only upon the showing of good cause, and extending the deadline only on agreement and/or judicial order. ${ }^{60}$ But the "fact period" of discovery remains an all-ornothing proposition: discover now or forever hold your peace. ${ }^{61}$

Practitioners note that hard discovery deadlines which cover the entirety of

546-48, 557 (2010) (citing a "noticeable lack of positive feedback when attorney [sic] do conduct efficient discovery," and stating that "[t]he bar must empower itself to seek knowledge on reasonable discovery.").

57. See Milberg LLP \& Hausfeld LLP, supra note 10, at 3.

58. Craig Ball, E-Discovery on a Budget, 3RD ANNUAL UF LAw/EDRM ELECTRONIC Discovery CONFERENCE MATERIALS (2015), http://www.edrm.net/2015-uflaw/materials ("Poor communication and lack of cooperation between parties on e-discovery issues contribute markedly to increased cost. The incentives driving transparency and cooperation in e-discovery are often misunderstood. You don't communicate or cooperate with an opponent to help them win their case on the merits; you do it to permit the case to be resolved on its merits and not be derailed or made more expensive by e-discovery disputes.").

59. Oot, supra note 56, at 537 (positing that under the current discovery regime, "all possible" relevant information becomes a money game).

60. Karl Schieneman \& Thomas C. Gricks III, The Implications of Rule 26(g) on the Use of Technology-Assisted Review, 7 FeD. CTS. L. ReV. 239, 255 \& n.54 (2013) ("The Federal Rules of Civil Procedure, case law, and the Sedona Principles all further emphasize that electronic discovery should be a party-driven process." (quoting Romero v. Allstate Ins. Co., 271 F.R.D. 96, 109 (E.D. Pa. 2010))).

61. Somewhat famously, in Justice Stevens's dissent in Bell Atlantic Corp. v. Twombly, he agreed with plaintiffs' proposal to phase discovery, stating that had he been the district court judge, he would have allowed key depositions to occur before dismissing the complaint. 550 U.S. 544, 591-93 (2007) (Stevens, J., dissenting); Suzette M. Malveaux, Front Loading and Heavy Lifting: How Pre-Dismissal Discovery Can Address the Detrimental Effect of Iqbal on Civil Rights Cases, 14 LewIS \& Clark L. Rev. 65, 135-36 (2010)). Commentators have pointed to this opinion and to phasing as an answer to accessto-justice issues inherent in heightened pleading standards. See, e.g., Ryan Mize, Comment, From Plausibility to Clarity: An Analysis of the Implications of Ashcroft v. Iqbal and Possible Remedies, 58 U. KAN. L. REV. 1245, 1265-66 (2010) (discussing minimal phased discovery). 
the discovery permissible in, and proportional to, a case are somewhat antithetical to "speediness," a goal of discovery so critical it appears in Federal Rule No. 1. Short time periods "may actually create incentives for requesting parties to issue overbroad requests (for fear they will have only a single opportunity to make such requests)." 62 This all-or-nothing system "can lead to massive document productions-along with expensive and time-consuming document reviews - much of which has only tangential relevance to the merits of the case." $" 63$

There is an inherent tension between a system that may be most beneficial for the litigants, but requires an all-or-nothing decision from lawyers not inclined to cooperate and operating with limited information. Taking that tension one step further, while there is hope that a renewed interest in discovery may limit discovery in some cases ${ }^{64}$ practitioners also fear that setting boundaries for discovery too early in the lifespan of a case, as the 2015 amendments encourage, may create a "mini trial" of sorts in which parties will litigate the scope of discovery extensively, defeating the purpose of keeping costs low. ${ }^{65}$ Put that way, the lack of success for the proportionality rule is not all that surprising.

Will the amendments finally create that success? That remains to be

62. Benning \& Toal, supra note 34.

63. Id.

64. See Benham, supra note 39 , at 2224-25.

Taken together, the amendments, combined with continued criticism of what some view as overbroad discovery, may create momentum in some courts to narrow the scope of discovery significantly, at least as a practical matter. For some commentators, the changes are a tepid step toward international litigation norms. Some in practice describe the potential change as almost cataclysmic. The truth is probably somewhere in the middle - the scope amendments will substantially narrow discovery in some cases but will not, as predicted by some, end pretrial litigation as we currently know it.

Id. (footnotes omitted).

65. Id. at 2224 ("At a minimum, the changes could prompt a wave of discovery disputes based on allegations that discovery requests are not proportional to the case. Reacting to the re-crafted scope provision, litigants and courts will undoubtedly pay more heed to proportionality."); see also Gelbach and Kobayashi, supra note 26, at 18:

Greater reliance on a judicially managed proportionality standard will involve a number of challenges. Will parties have the proper incentives to report the information that judges need to carry out proportionality analysis? Will the parties even have that information at the time that the standard will be applied? How will judges determine the implicit weight to place on nonquantifiable factors involving the importance of nonmonetary issues in a case? How good a job will judges do forecasting the merits value of the (yet-to-be-provided) requested information in question? Whatever the answers to these questions, we can expect an increase in the variation in adjudication due to the discretionary factors written into the proportionality standard.

The result of that mini-trial will not likely be overturned on appeal, given appellate courts' general deference to the trial court's judgment in discovery disputes. See, e.g., Nat'l Hockey League v. Metro. Hockey Club, Inc., 427 U.S. 639, 642 (1976) (holding that discovery disputes are reviewed under an abuse of discretion standard, where the question is not whether the appellate court "would as an original matter have [acted as the trial court did]; it is whether the [trial court] abused its discretion in so doing."). 
seen. Months before their adoption, a federal court used its discretion to apply proportionality in the spirit of the 2015 amendments. In a February 2015 case, Adair v. EQT Production Co., a class action, the court limited discovery beyond a certain boundary because the burden and expense of obtaining it outweighed a likely benefit, citing a "yardstick of proportionality" in doing so. ${ }^{66}$ The court specifically cited the then-forthcoming 2015 amendments as guidance in formulating this limitation. ${ }^{67}$

Consider also Siriano v. Goodman Manufacturing Co., ${ }^{68}$ one of the first 2015 opinions using the recently-revised proportionality rule. ${ }^{69}$ This was a products liability case in which the defendant balked at certain discovery, stating that it would be unduly burdensome to review and produce. ${ }^{70}$ The magistrate judge stated that "'restoring proportionality' was the 'touchstone of revised Rule 26(b)(1)'s scope of discovery provisions' with the move of proportionality from Fed. R. Civ. P. 26(b)(2)(C)(iii)) to Fed. R. Civ. P. 26(b)(1)." ${ }^{71}$ Finding that the discovery in question was potentially important albeit difficult to produce, "the Court ordered a discovery conference to discuss possibly conducting discovery in phases. ${ }^{72}$ The Court also charged the parties to "engage in further cooperative dialogue in an effort to come to an agreement regarding proportional discovery." ${ }^{73}$

These judges still had to use discretion, take guidance, and put forth substantial effort to instill proportionality in these particular cases. To that, end, do the 2015 amendments go far enough? Could they do more?

\section{A Proposed PRoportionality SOLUTION: MANDATORY Phased DISCOVERY}

What this Article proposes is that, in many cases, judges should be required to create scheduling orders to require the parties to "phase" discovery.

66. Adair v. EQT Prod. Co., No. 1:10CV00037, 2015 WL 505650, at *5-6 (W.D. Va. Feb. 6, 2015); Brian K. Cifuentes, Proportionality: The Continuing Effort to Limit the Scope of Discovery, Metropolitan CorP. Couns. (March 18, 2015, 5:21 PM), http://www.metrocorpcounsel.com/articles/31951/proportionality-continuing-effort-limitscope-discovery (discussing Adair).

67. Id.

68. Siriano v. Goodman Mfg. Co., L.P., No. 2:14-cv-1131, 2015 U.S. Dist. LEXIS 165040 (S.D. Ohio Dec. 9, 2015).

69. See, e.g., Joshua Gilliland, Proportionality is like The Force, Bow TIE LAw's BloG, (Dec. 22, 2015), https://bowtielaw.wordpress.com/2015/12/22/proportionality-is-likethe-force (last visited: Dec. 22, 2015).

70. Id. (citing Siriano, 2015 U.S. Dist. LEXIS 165040, at*15).

71. Id. (quoting Siriano, 2015 U.S. Dist. LEXIS 165040, at*16).

72. Id. (emphasis added).

73. Id.(quoting Siriano, 2015 U.S. Dist. LEXIS 165040, at *20). The Court further noted that Rule 1 now charges the Court and the parties with ensuring a "just, speedy, and inexpensive determination of every action and proceeding." Id. (quoting Siriano, 2015 U.S. Dist. LEXIS 165040, at*19). 
That is to say, at the outset of the case, the judge orders the parties to meet-andconfer as part of their Rule 26 organizations and attempt to set a scope of discovery, as prescribed by the revised rules. But the proposed judicial action here goes much farther, in that the judge would also ask the parties to meet and confer with respect to the most important facts to be discovered, and the most important information custodians for each side. With that knowledge in hand, the judge would ask the parties to set a "first phase" of discovery, at the initial Rule 16 conference, covering only the most important discovery. Should the parties fail to reach an agreement, the judge would then set the scope and timing of the "first phase" based on submissions from the parties as to what that first phase should be, using the standards set by courts to set the scope of discovery as a guide.

That is to say, it makes sense for judges looking for guidance in setting the scope of phases to look to some of the Rowe Entertainment factors for proportionality, specifically: (1) the likelihood of discovering critical information; (2) the availability of such information; (3) the purposes for which the responding party maintains the requested data; (4) the relative benefit to the parties of obtaining the information; (5) the total cost associated with discovery; (6) the relative ability of each party to control costs and its incentive to do so; and (7) the resources available to each party.

At the end of this first phase of discovery, the judge would bring the litigants together at a subsequent "discovery" conference, which can (and should) double as a settlement conference. ${ }^{74}$ At this conference, the parties would discuss whether any additional discovery is necessary, and if so, whether they have met and conferred so as to agree upon its scope. If the parties cannot agree, the judge would, at his or her discretion, set an additional phase of discovery. In theory, the number of phases would be unlimited; in practice it is likely to be a relatively low number as parties will, with any effort and luck, uncover the ultimate facts in a case, or at least sufficient facts in a case to support a resolution of the dispute. ${ }^{75}$

Indeed, nearly this exact system is contemplated by the Committee Notes to the 2015 Amendments:

The parties may begin discovery without a full appreciation of the factors that bear on proportionality. A party requesting discovery, for example, may have little information about the burden or expense of responding. A party requested to provide discovery may have little information about the

74. There can, but does not need to be, a determination at the outset of discovery of a set number of phases. Judges who want to calendar cases long-term with more consistency might estimate a reasonable number of phases and build them into a scheduling order; other judges may schedule all dates but make them subject to change in the event of additional discovery phasing.

75. Yablon and Landsman-Roos, supra note 15, at 742 ("A court orders phased discovery in the hope that the information disclosed in that partial discovery will make further discovery unnecessary.") 
importance of the discovery in resolving the issues as understood by the requesting party. Many of these uncertainties should be addressed and reduced in the parties' Rule 26(f) conference and in scheduling and pretrial conferences with the court. $^{76}$

The driving thrust of the theory is that cases will settle early, upon discovery of the most important evidence. Phased discovery compels litigants to formally assess the strength of their case theory at pre-set benchmarks, during which they must evaluate the discovered material. ${ }^{77}$

That is to say, after the most important discovery in a case is complete, the parties should have enough sense of the admissible facts in a case to discuss settlement on potentially more fruitful grounds. A savvy judge could even entertain and decide motions in limine with respect to the most important evidence of a case in between phases as a way to better provide a sense to the parties of what may lurk ahead for them at trial. The idea of deciding a motion in limine on an evidentiary issue before summary judgment is a little odd but really should not be. After all, it is certainly helpful for summary judgment briefing, at the very least. It is another step toward the long-discussed realization that the overwhelming majority of civil cases do not go near adjudication at a trial. ${ }^{78}$ Rather, the cases are decided in pretrial discovery and motion practice, as each side builds a case and shows it off in the most effective way possible. Settlements generally happen when one party (or more) has seen enough. Phased discovery and inter-phase motions in limine are ways to establish and decide enough of a case so that it can settle.

\section{A. Phasing Has Worked}

Phased discovery is not new. It has been around and it works. ${ }^{79}$ That is to

76. FED. R. Civ. P. 26, 2015 Committee Notes supra note 42, at B-40.

77. Proportionality achieves this goal, albeit somewhat less stringently. See MichAEL J. Hanrahan, Game-Changing Federal "Proportionality" Discovery Rule Effective December 1, 2015, Fox, O’NeIll, Shannon, S.C., (Oct. 21, 2015), $\mathrm{http}: / / \mathrm{www}$.foslaw.com/news-views/game-changing-federal-proportionality-discovery-ruleeffective-december-1-2015 (last visited December 22, 2015) ("The new [proportionality] standard cuts both ways. It prevents plaintiffs from using discovery to extract a 'cost of defense' settlement (especially in a small case), and checks defendants' prying into a plaintiff's background/finances when the yield is low.").

78. See, e.g., Marc Galanter \& Mia Cahill, Most Cases Settle: Judicial Promotion and Regulation of Settlements, 46 StAN. L. Rev. 1339, 1339-40 (1994); Samuel R. Gross \& Kent D. Syverud, Getting to No: A Study of Settlement Negotiations and the Selection of Cases for Trial, 90 Мich. L. REv. 319, 320 (1991) ("A trial is a failure. ... [L]awyers, judges, and commentators agree that pretrial settlement is almost always cheaper, faster, and better than trial.").

79. See, e.g., Bennett, supra note 30, at 457 n.103 (citing Laura Hunt, Comments: Trending: Proportionality in Electronic Discovery in Common Law Countries and the United States' Federal and State Courts, 43 Univ. OF BALT. L. Rev. 279, 298-303 (2014) (referring to phasing as a technique to ease discovery burdens); Matthew A. Bills, 9 Ways to Reduce E-discovery Costs; From the Experts, 2013 CoRP. Couns. 1, 1 (Sept. 6, 2013) 
say, in certain exemplary instances courts and parties have purposefully placed their initial focus on the most important, relevant or determinative information first, choosing to restrict the contours of discovery to exclude other information, even if that information would otherwise be discoverable, relevant, or probative. ${ }^{80}$ Leading commentators cite it with approval. ${ }^{81}$

In Haka v. Lincoln County, ${ }^{82}$ a magistrate judge implemented phasing when faced with a classic proportionality problem. The case, a wrongful termination action, involved a relatively low amount in dispute compared to the

("conducting discovery in phases is an effective way to reduce costs by focusing the parties' time and effort on the most critical discovery at the outset"); Hon. Paul W. Grimm, The State of Discovery Practice in Civil Cases: Must the Rules Be Changed to Reduce Costs and Burdens, or Can Significant Improvements Be Achieved Within the Existing Rules?, 12 SEDONA CONF. J. 13 (2011) ("[The parties] can phase the discovery to focus first on a limited sub-set of witnesses and documents that are most likely to yield the most evidentiary 'bangfor-the-buck,' while reserving the right to seek additional discovery in the future if warranted by what the initial discovery has disclosed."); Sean R. Gallagher, Bringing Proportionality Back into the Discovery Process: E-Discovery for the Other 97\% of Us, 2013 A.B.A. SYMP. ON TECH. \& EMP. L. 1, 11 (Apr. 23, 2013), http://www.americanbar.org/content/dam/aba/events/labor_law/2013/04/aba_national_symp osiumontechnologyinlaboremploymentlaw/17_gallagher.authcheckdam.pdf (last visited Dec. $22,2015)$ (recommending phasing so that parties can be "better positioned to target future discovery in a more efficient manner"); Milberg LLP, Hausfeld LLP, supra note 10, at 33 (Describing phasing upon agreement of counsel as an example of cooperation as a system that "would incorporate a schedule whereby certain tranches of information would be produced in sequence, and, in some instances, subject to the satisfaction of certain thresholds. For example, counsel for the parties might agree to initiate discovery with the production of information from the files of a set number of custodians, departments, or both, with subsequent productions of other information from other custodians or departments to be permitted only if certain showings are made.").

80. The Sedona Conference features phasing in its most recent Commentary on Proportionality, published in 2013, in which they write:

Under these circumstances, the court, or the parties on their own initiative, may find it appropriate to conduct discovery in phases, starting with discovery of clearly relevant information located in the most accessible and least expensive sources. Phasing discovery in this manner may allow the parties to develop the facts of the case sufficiently to determine whether, at a later date, further discovery that is more burdensome and expensive is, nevertheless, warranted. In addition, given that the vast majority of cases settle, phasing discovery may allow the parties to develop a factual record sufficient for settlement negotiations without incurring the costs of more burdensome discovery that may only be necessary if the case goes to trial.

The Sedona Conference Commentary on Proportionality in Electronic Discovery, (Jan. 2013) at 9, www.thesedonaconference.org (click "Publications" tab; then click "Sedona Conference Commentary $\mathbb{C}$ on Proportionality" under "eDiscovery").

81. See Losey, Predictive Coding, supra note 18, at 43:

In my opinion, electronic discovery production should almost always be conducted in phases. This is in accord with Sedona's second principle of proportionality, that, in general, litigants should seek discovery from the most convenient, least burdensome, and least expensive sources. As The Sedona Conference Proportionality Commentary indicates, parties should always focus first on the low-hanging fruit. In other words, they should focus first on evidence that is likely to have the most probative value and that is the most easily accessible.

(citing Sedona, Commentary on Proportionality (2013), supra note 80, at 8-9).

82. Haka v. Lincoln County, 246 F.R.D 577 (W.D. Wis. 2007). 
cost of reviewing the ESI. Faced with a classic proportionality problem, the magistrate judge went through the factors set forth in the existing Rule 26(b)(2)(C), seeming to struggle somewhat with balancing the monetary aspect of the case with the recognition that it involves a violation of important rights for the plaintiff. ${ }^{83}$ It was clear that the cost to review and produce ESI would near the amount in dispute somewhat quickly. The magistrate judge recognized that neither party "ha[d] deep pockets." ${ }^{\circ 4}$ Here, phasing and proportionality provided the solution:

Having considered all the relevant factors, I conclude that fairness and efficiency require the parties to proceed incrementally, limiting the initial search to the e-mails stored on the hard drives. Plaintiff is required to narrow his search terms to the narrowest set with which he is comfortable. Any additional searches shall occur only by joint agreement or court order. ${ }^{85}$

The costs of additional phases of discovery were to be split between the parties equally. This case is a great example of an "easy" phasing case; the discovery costs would have turned it into a "nuisance settlement," and the interests of fairness dictated at least taking a chance at finding the most important evidence in a first phase.

Haka was an easy case. In a somewhat harder case, Mancia v. Mayflower Textile Services Co. ${ }^{86}$ a FLSA case, then-Magistrate Judge Grimm noted that given the potential amounts in controversy plaintiff's requested discovery "might be excessive or overly burdensome," but he lacked sufficient information to make an informed ruling on that theory. ${ }^{87}$ Thus, the parties were asked to estimate the potential damages, with zero being the best case scenario for defendants, and with plaintiffs calculating the worst case scenario for defendants. ${ }^{88}$ Then-Magistrate Judge Grimm noted that "[w]hile admittedly a rough estimate, this range is useful for determining what the 'amount in controversy' is in the case, and what is 'at stake' for purposes of Rule $26(\mathrm{~b})(2)(\mathrm{C})$ 's proportionality analysis ${ }^{89}$ The purpose of this exercise was to help the parties set a proportional budget for discovery. ${ }^{90}$ In doing so, thenMagistrate Judge Grimm recommended phasing discovery, which would, inter alia, "enable Plaintiffs to reevaluate their needs depending on the information already provided." 91 The judge stressed that the parties' collaborations on

83. Id. at 579 ("Although the issues at stake in this lawsuit are important, the potential damages are low, so that the cost of engaging in the ESI search plaintiff needs is disproportionate to the available recovery.").

84. Id.

85. Id.

86. Mancia v. Mayflower Textile Servs. Co., 253 F.R.D. 354, 364 (D. Md. 2008).

87. $I d$.

88. Id.

89. Id.

90. Id.

91. Id. at 365 . 
phase discovery would result, for the defendants, in "having to produce less discovery, at lower cost," and for the plaintiffs, "in getting helpful information more quickly." 92 Both parties would save money, and in negotiating the phases of discovery, the judge surmised that this process would "expedit[e] the time when the case may be resolved on its merits, or settled." $" 93$

Why phasing would expedite resolution is not answered in the opinion but seems based on the idea that getting more discovery sooner and cheaper will facilitate settlement. ${ }^{94}$ But this opinion also suggests another benefit that is less obvious: that through negotiating phases, the parties will learn the strengths and weaknesses of both cases, which can bring about a settlement as well. ${ }^{95}$

In another well-cited case, Barrerra v. Boughton, ${ }^{96}$ defendants accused of racial profiling dug in against allegedly overbroad discovery requests from a plaintiff that included forty custodians, an eighty-keyword search, and an allegedly expansive date range. ${ }^{97}$ The defendants cited unduly burdensome costs for such a large, one-shot discovery and proposed an initial phase of three custodians over a limited date range. ${ }^{98}$ Plaintiffs refused to phase discovery, or perhaps, put more diplomatically by the court, plaintiffs "could not agree" on a first phase. ${ }^{99}$ The court sided with defendants, and ordered the parties to attempt a first phase of discovery along the lines proposed by defendants. ${ }^{100}$ At the time, commentators noted that "[t]he Court's order for phased discovery highlights a practical approach in searches of multiple custodians."

92. Id.

93. Id.

94. Judge Grimm expressly states this point. See Grimm, The State of Discovery, supra note 79, at 23 ("Judges who have ordered phased discovery, focusing first on that which is most likely to reveal the most relevant information, permitting the parties to seek additional discovery later (albeit with the possibility of cost-shifting), have found that they seldom return for more. Rather, they cooperate in identifying key inquiries and information and the most efficient means to discover it. If the parties then find that they must seek additional discovery, that request is generally based on a far more accurate showing of need.").

95. See, e.g., Milberg LLP, Hausfeld LLP, supra note 10, at 9 n.26 (citing Judge Posner that "A full exchange of the information ... enabl[es] each party to form a more accurate, and generally therefore a more convergent, estimate of the likely [case] outcome." RiCHARD A POSNER, ECONOMIC ANALYSIS OF LAW 571 (6th ed. 2003). Most cases never go to trial, so a settlement is essentially inevitable. See Mark R. Kravitz, The Vanishing Trial: A Problem in Need of Solution?, 79 ConN. B.J. 1 (2005).

96. Barrera v. Boughton, No. 3:07cv1436, 2010 WL 3926070, at*3 (D. Conn. Sept. 30, 2010).

97. $I d$. at 2 .

98. $I d$.

99. Id.

100. Id.

101. Joshua Gilliland, Phased Discovery: Undue Burden and Practical Proportionality,Bow TIE LAw's BLoG, (Oct. 7, 2010), https://bowtielaw.wordpress.com/2010/10/07/phased-discovery-undue-burden-and-practicalproportionality (Last visited: December 22, 2015). 
Perhaps the most well-known example of phasing is that in place for cases before Judge Paul Grimm in the United States District Court of Maryland. ${ }^{102}$ Grimm plainly states that he requires a two-step phasing of discovery in his cases because "Fed. R. Civ. P. 26(b)(2)(c) and 26(g)(1)(B)(iii) require that discovery in civil cases be proportional to what is at issue in the case, and require the Court, upon motion or on its own, to limit the frequency or extent of discovery otherwise allowed to ensure that discovery is proportional."103

Grimm requires a first phase that is different from that described in this article:

Phase 1 Discovery. The first phase of discovery should focus on the facts that are most important to resolving the case, whether by trial, settlement or dispositive motion. Accordingly, the parties' Phase 1 Discovery may seek facts that are not privileged or work product protected, and that are likely to be admissible under the Federal Rules of Evidence and material to proof of claims and defenses raised in the pleadings. Phase 1 Discovery is intended to be narrower than the general scope of discovery stated in Rule 26(b)(1) ("discovery regarding any nonprivileged matter that is relevant to any party's claim or defense," even if not admissible, if "reasonably calculated to lead to the discovery of admissible evidence"). ${ }^{104}$

Here Judge Grimm contemplates the most important discovery first, and an initial scope narrower than the current "one shot" discovery. ${ }^{105}$ This is very similar to the phasing discussed in this article. However, he does require that the first phase material discovery be "material to proof of claims and defenses raised in the pleadings." This limitation is commonsensical but may make the first phase too narrow. First, it adds a bar to the first phase that provides an opportunity for parties to fight as to whether certain discovery is sufficiently "material" as to be included in the first phase. If the parties were to believe certain facts that could bear on settlement may not necessarily be material to claims and defenses raised in the pleadings, but want to include them in the first phase, it makes sense to do so.

Grimm's second phase creates somewhat of an all-or-nothing discovery:

Phase 2 Discovery. Unless the parties stipulate otherwise, the Court, upon a showing of good cause, may permit discovery beyond that obtained under Phase 1 Discovery. In Phase 2 Discovery, the parties may seek discovery of facts that are not privileged or work product protected, are relevant to the claims and defenses pleaded or more generally to the subject matter of the litigation, and are not necessarily admissible under the Federal Rules of Evidence, but are likely to lead to the discovery of admissible evidence. A

102. See Judge Paul Grimm, "Discovery Order," United States District Court, District of Maryland, available at:

https://thesedonaconference.org/system/files/Judge\%20Grimm\%20Discovery\%20Order.pdf (Last visited: December 22, 2015).

103. Id.

104. Id. at 92 (a) (emphasis omitted).

105. Id. 
showing of good cause must demonstrate that any additional discovery would be proportional to the issues at stake in the litigation, taking into consideration the costs already incurred during Phase 1 Discovery and the factors stated in Rule 26(b)(2)(C)(i)- (iii). If the Court determines that additional discovery is appropriate, the Requesting Party will be required to show cause why it should not be ordered to pay all or a part of the cost of the additional discovery sought. ${ }^{106}$

Judge Grimm's second phase is optional, and any discovery therein must survive a showing of good cause not only that the discovery would be proportional, given the costs already expended, but that costs of that discovery should not be charged to the requesting party. While certainly effective at countering potential abuse, the scope of this phase does lend itself to making discovery more of an "all or nothing" endeavor in the first phase. A party must set the first phase knowing that it risks bearing the full expense of such discovery if it cannot convince Judge Grimm that costs should be shared.

The system of phasing proposed by this article is not as strict, though a judge certainly could (and in some cases, should) fashion such restrictiveness into subsequent phases. For example, a third or fourth phase in discovery almost certainly should carry with it some measure of cost shifting, and/or be limited in scope.

\section{B. Phasing Fits Within the Rules}

Commentators have often described phasing as a natural technique to implement the proportionality concept, particularly in large volume cases. ${ }^{107}$ "Properly used, the proportionality tools available under the Federal Rules of Civil Procedure can go a long way toward reaching the long sought-after goal

106. Id. at 92 (b) (emphasis omitted).

107. See Carroll, supra note 54, at 460-61; see also Tonia Hap Murphy, Mandating Use of Predictive Coding in Electronic Discovery: An Ill-Advised Judicial Intrusion, 50 AM. Bus. L.J. 609, 647-48 (2013):

While FRCP Rule 26(b) explicitly grants courts the power to "limit" discovery, case law shows that courts have imposed "limitations" to address proportionality problems, in cases where the requested discovery was overly burdensome or costly, given the nature of the case or the value of the information likely to be gained. This is consistent with the advisory committee notes accompanying this rule. Orders to limit the number of interrogatories, limit the universe of ESI to be examined, or phase discovery fit the plain meaning of the word "limit." Ordering a party to employ a different technology to search its own ESI would be unlike those sorts of limitations and does not go to a concern about proportionality. Such an order would not naturally be regarded as a "reduction" or "restriction" of discovery.

Phasing is also found in the prior rules. See Fed. R. Civ. P. 26(b)(2) advisory committee's notes to 2006 amendment (noting that, "because the court and parties may know little about what information the sources identified as not reasonably accessible might contain, whether it is relevant, or how valuable it may be to the litigation," it may be appropriate for the parties to engage in "focused discovery ... to learn more about what burdens and costs are involved in accessing the information, what the information consists of, and how valuable it is for the litigation in light of information that can be obtained by exhausting other opportunities for discovery."). 
of Rule 1: securing the "just, speedy, and inexpensive determination of every action and proceeding." "108 Indeed, the purpose of phased discovery is to bring suits to an end as fast as possible; as one commentator writes, "a court orders phased discovery in the hope that the information disclosed in that partial discovery will make further discovery unnecessary."109 The end goal of phasing is quicker settlements, which goes to the heart of the cost-of-discovery versus cost-of-litigation problem.

Of course, much of the past scholarship has viewed phasing as an optional tool that litigants can use to meet the goal of proportional discovery. The new rule suggests that the tool is not so optional, but does not seem to require much more than an awareness or conversation about the scope of discovery. What is proposed here is more radical; here a judge requires the parties to phase discovery, whether the attorneys want to or not.

Judges would retain their discretion to determine (or better yet, allow parties to determine) what discovery fits into each phase. For example, in many cases, a first phase dedicated to evidence of liability would be appropriate before a second phase dedicated to evidence of damages. Similarly, a case might be split into phases that track the key legal requirements of each claim. A breach of contract case, for example, might proceed with discovery regarding an existence of contract, then a phase regarding a breach, and so forth.

Another potential benefit of phasing is that it adds "teeth" to the exercise in which litigants must cooperate to achieve a common goal. The conversation and awareness required by the revised rule now has a set outcome; the parties know that discovery will be limited in the short term. ${ }^{110}$

Further, phasing sets a potentially more reasonable goal in that litigants do not have to agree on the total scope of discovery at the outset of a case; rather they must agree on the most important discovery, to be covered first. ${ }^{111}$ Of course, one could argue that the more specific the goal of a consensus, the more difficult it is to obtain. ${ }^{112}$

108. Carroll, supra note 54, at 461.

109. See Yablon and Landsman-Roos, supra note 15, at 742; see also Tamburo v. Dworkin, No. 04 C 3317, 2010 WL 4867346, at *3 (N.D. Ill. Nov. 17, 2010) (ordering phased discovery so as to keep discovery proportional and bring about a speedy resolution to a case, specifically "to ensure that discovery is proportional to the specific circumstances of this case and to secure the just, speedy, and inexpensive determination of this action ....").

110. See, e.g., Grimm, supra note 102, at 93 ("[T] he parties and counsel are expected to work cooperatively during all aspects of discovery to ensure that the costs of discovery are proportional to what is at issue in the case ....").

111. See Sedona Conference Commentary, supra note 80, at 9 ("Parties who wish to conduct phased discovery must communicate with one another about the issues relevant to the litigation and the repositories - both accessible and inaccessible - that may contain relevant information. Moreover, the parties must cooperate with one another to prepare and propose to the court a phased discovery plan.").

112. It is relatively easy to obtain consensus among a group of hungry people that pizza should be ordered; agreeing on toppings is another story. 
However once again, a rule should not be disregarded simply because it is difficult to follow. Difficult times require difficult rules. There is much support for the notion that increased cooperation amongst opposing counsel and parties in discovery is absolutely essential to the sustainability of the discovery process in light of big data. ${ }^{113}$ As admitted herein, there simply are not enough judicial resources to carefully monitor each and every case from a granular discovery perspective. Phasing-like all discovery-therefore cannot work effectively without consistent and effective cooperation among counsel. ${ }^{114}$

Provided such cooperation exists, phasing carries the added benefit of providing a mechanism for the parties to agree on the key issues in the case. This is not far from an existing requirement of Rule 26(f)(2) that is often overlooked by commentators and certainly by counsel, in that the parties must, as part of their Rule 26 conference, "consider the nature and basis of their claims and defenses and the possibilities for promptly settling or resolving the case." 115 Agreeing on the most important discovery in a case so as to set phase one of discovery in a mutually agreed fashion requires the parties to consider the nature and basis of claims and defenses, and to a limited extent, share them with the other side. This agreement can only help settlement, even if it ruins tactical plans and "hide the ball" games.

By creating a greater, more collaborative dialogue, parties move ever closer to agreeing on a resolution of the lawsuit; given the statistics with respect to cases settling versus going to trial, this resolution can be called nearly inevitable. In this sense phasing is more than idealistic; it is pragmatic, as it speeds cases along to their likely conclusion at a settlement table.

\section{WHAT COULD POSSIBLY Go WRONG? EXAMINING THE COUNTERARGUMENTS}

Mandatory phasing lends itself to a certain amount of criticism, mainly of the "what if?" variety. Part III of this Article discusses these potential criticisms and examines whether they are real or paper tigers.

It would be easy to dismiss all criticism of phased discovery to be a kneejerk reaction borne of inertia. After all, for many years, discovery has generally been a one-phase, one-shot at the truth with all information reasonably calculated to lead to discoverable evidence in the boat. Stepping

113. For a good survey of this point, see Bennett, supra note 30, at 441-45.

114. Professor Steven Gensler, in an essay, describes cooperation among counsel with an analogy of a dartboard with a bulls-eye, where the outer rings are the bare minimum cooperation required by civility, and the middle rings are an honest and forthright sense of collaboration among counsel to bring about an efficient resolution of the dispute. See Scheindlin \& Capra, supra note 9 , at 273 . He cites phased discovery as an example of cooperation in the bulls-eye, as an example of the highest level of cooperation, and one towards which attorneys should strive. Id.

${ }^{115}$ FED. R. CIV. P. 26(f)(2). 
away from that system to a phased discovery system requires a leap of logic that resembles a leap of faith: an admission that all information that is tangentially relevant to a case is flat out unnecessary to obtain a satisfactory resolution of a dispute, even after trial. ${ }^{116}$ Once this philosophical hurdle is overcome, there are several potential issues with compulsory phased discovery worth examining:

- First, it could be said that phased discovery stretches already thin judicial resources, particularly in cases where the parties cannot agree to the scope of the phases.

- Next, phased discovery may obfuscate a "drop dead" end date for discovery, which complicates court calendars and litigant expectations.

- Further, phased discovery brings added deadlines and calendaring, and so may lengthen cases, particularly because legal work often expands to fit the time required for its completion.

- Similarly, a dishonest litigant could misuse phased discovery to drag out a case, creating added cost and waste.

- More practically, splitting discovery into phases may create redundancy as parties "go back over" prior discovery and, in some cases, need to re-depose witnesses.

- Lastly, phased discovery may be hard to implement in cases where intangible constitutional rights are at stake and the most important evidence may be less clear.

This section describes each stated issue in turn.

\section{A. "Phased Discovery Stretches Judicial Resources Too Thin"}

The genesis of this criticism is a legal truism: the more judges have to oversee, the more work it takes for them to provide oversight. ${ }^{117}$ Phased

116. See Carroll, supra note 54, at 459 (citing In re Convergent Techs. Sec. Litig., 108 F.R.D. 331 (N.D. Cal. 1985)):

[The 1983] amendments formally interred any argument that discovery should be a free form exercise conducted in a free for all spirit. Discovery is not now and never was free. Discovery is expensive. The drafters of the 1983 amendments to sections (b) and (g) of Rule 26 formally recognized that fact by superimposing the concept of proportionality on all behavior in the discovery arena. It is no longer sufficient, as a precondition for conducting discovery, to show that the information sought "appears reasonably calculated to lead to the discovery of admissible evidence." After satisfying this threshold requirement counsel also must make a common sense determination, taking into account all the circumstances, that the information sought is of sufficient potential significance to justify the burden the discovery probe would impose, that the discovery tool selected is the most efficacious of the means that might be used to acquire the desired information (taking into account cost effectiveness and the nature of the information being sought), and that the timing of the probe is sensible, i.e., that there is no other juncture in the pretrial period when there would be a clearly happier balance between the benefit derived from and the burdens imposed by the particular discovery effort.

117. This oversight is proper, in that courts have broad case management authority. See 
discovery can, and should, operate with little judicial intervention, just like the current system of proportional discovery. But the statistics, common perception, and scholarship all agree that proportional discovery is not working that way, meaning that judicial intervention may need to become more prevalent in a mandatory phased system.

But how much oversight would a phased discovery system require? Setting a first phase of discovery with or without consensus of the parties would require no more additional work from a chambers than setting a proportional scope as required by the 2015 amendments to the discovery rules. The additional work occurs later in discovery when, instead of managing the end of a discovery period that is all-encompassing, the judge is managing the end of a discovery period that may continue into the future. ${ }^{118}$ The judge would then be determining what discovery, if any, should be part of the next phase. This activity itself is not much different than a case ongoing today in which a singlephase discovery period is about to end, and a litigant is arguing that because of recently-discovered facts, "hide the ball" misconduct, or temporal limitations that the discovery period be extended and/or the scope of discovery heightened. In other words, many complex litigations today are multi-phase cases; they just look like single-phase cases in which the sole fact discovery deadline is "kicked" one or more times. ${ }^{119}$

It is certainly possible that in some instances a party will argue for a tranche of information to be included in Phase one of discovery, not get their way, and just plunge forward with that discovery in Phase one, requiring limited judicial intervention to put an end to such transgression. In this sense a savvy judge will assist the parties in setting phases, then utilize a magistrate or discovery master for "problem" cases, as extensive judicial oversight may be difficult. ${ }^{120}$

FED. R. CIV. P. 16(c)(2)(F) (courts' broad authority over timing of discovery); FED. R. CIV. P. $16(\mathrm{c})(2)(\mathrm{E})$ (timing of summary judgment motions).

118. Indeed, this "extra work" often happens anyway. See SEDOna Conference COMMENTARY, supra note 80 , at 12 ("[C]ourts generally consider extrinsic information submitted by the parties to determine whether requested discovery is sufficiently important to warrant potentially burdensome or expensive discovery. Such evidence may include the parties' opinions regarding the likely importance of the requested information, whether the requested information was created by 'key players,' whether prior discovery permits an inference that the requested information is likely to be important, whether the creation of the information requested was contemporaneous with key facts in the case, and whether the information requested is unique.").

119. Experienced litigators know that, in most cases, it is not difficult to "kick" a discovery deadline. Under FED. R. CIV. P. 16(b)(4), for a party to secure modification of the scheduling order, it must demonstrate good cause and obtain the judge's consent. To meet the good cause standard, the party must show that, despite its diligence, it could not reasonably have met the scheduling order deadline. See S\&W Enters., L.L.C. v. SouthTrust Bank of Ala., N.A., 315 F.3d 533, 535 (5th Cir. 2003).

120. William Hubbard, The Discovery Sombrero and Other Metaphors for Litigation, 64 CATH. U. L. REV. 867, 903 (2015) ("Parties should be provided tools to reduce discovery 
Will it require more work than the emphasized proportional discovery under the 2015 amendments? Perhaps not. After all, the amendments clearly contemplate a judge setting limits on discovery that are narrower than the current broad scope. Further, the hope of phased discovery is that it results in less discovery, less disruption, and quicker settlements. If it works as it should in the aggregate, the reduction in judicial work on the cases for which it works should outweigh the increase in judicial work for "problem" cases.

Further, the Chief Justice has strongly suggested that judges need to spend more time managing discovery:

[Under the 2015 amendments] [j]udges must be willing to take on a stewardship role, managing their cases from the outset rather than allowing parties alone to dictate the scope of discovery and the pace of litigation. Faced with crushing dockets, judges can be tempted to postpone engagement in pretrial activities. Experience has shown, however, that judges who are knowledgeable, actively engaged, and accessible early in the process are far more effective in resolving cases fairly and efficiently, because they can identify the critical issues, determine the appropriate breadth of discovery, and curtail dilatory tactics, gamesmanship, and procedural posturing. ${ }^{121}$

Even if phasing does create an extra workload for judges, such, unfortunately, is the reality of modern litigation.

\section{B. "Phased Discovery Creates Discovery Without End"}

There is a perceived advantage in single-stage discovery: a "hard" discovery deadline date, held by a strong-handed judge, will result in time- and content-certainty to discovery not present in a multi-phase system. A phased discovery, one could argue, lacks that benefit. Since nobody will know when discovery will actually end, nobody will know when the trial will be. Since no litigant can effectively budget for the great unknown, no litigant can effectively set a meaningful settlement figure. Thus phased discovery becomes a war without end that actually drags on and is more, not less, expensive. Also, the concern is that phase discovery may make it hard for judges and parties to know from the outset of a case how involved subsequent phases of discovery will be such that setting a trial date may be hard.

However, as described above, in many instances, many complex litigations today suffer from extended discovery deadlines due to logistical issues, newlydiscovered facts, and tomfoolery. ${ }^{122}$

costs because active judicial oversight of discovery, although widely praised as highly effective, rarely occurs.").

121. ROBERTS 2015 REPORT, supra note 41 , at 7, 10.

122. For example, in Anthony Biddle Contractors, Inc. v. Preet Allied American Street, LP, 28 A.3d 916, 925-26 (Pa. Super. Ct. 2011) the Pennsylvania Superior Court referred to hard discovery deadlines as tantamount to termination of the action, and urged trial courts to be lenient in granting extensions. 
Setting a trial date has long been recognized as a way to keep litigation moving, and foment settlement, ${ }^{123}$ but multi-phase discovery does not prevent a judge from setting a trial date. It merely means that the judge should consider additional phases of discovery into the schedule before setting it. This situation can, and should, mean that a case that ordinarily may require four months of discovery has a first phase set with a deadline two months out, with the expectation that further phases may, but need not, follow. Therefore, the schedule in a multi-phased case is, at the end, the same schedule as before, but with fact discovery split into separate segments. Therefore, the trial date can be set at the outset of the case with some manner of certainty.

Lastly, any lack of certainty caused by the specter of endless phases of discovery can be offset by the entire point of phased discovery in the first place: that after the most important discovery in a case is complete, the parties get enough of a sense of the admissible facts in a case to settle the whole mess. ${ }^{124}$ There should be an inherent offsetting value in that proposition.

All of this is not to deny that, in certain cases, phased discovery will provide some uncertainty. That is why the theory articulated by this Article is to keep phasing strongly recommended, but ultimately optional. There are certain cases in which phased discovery may not be appropriate. These cases will be discussed more specifically in section 7 .

\section{C. "Phased Discovery Will Take Too Long and Cost Too Much"}

The next criticism of phased discovery is that phased discovery equals a longer discovery period, and a case with a longer discovery period will cost more money because it takes longer to resolve. Key to this criticism is the observation that legal work is particularly susceptible to "Parkinson's Law," which, as propounded by the twentieth-century British scholar C. Northcote Parkinson, states, "work expands to fill the time available for its completion." $" 125$

Critics of the billable hour have long said that its underlying premise lends itself to inefficiency, among many other dubious characteristics. ${ }^{126}$ That is to

123. Andrew J. Wistrich \& Jeffrey J. Rachlinski, How Lawyers' Intuitions Prolong Litigation, 86 S. CAL. L. REV. 571, 576 n. 17 (2013) (citing Malinda M. Sanders, Settlement on the Courthouse Steps, 61 BENCH \& B. MinN. 16 (Sept. 2004) (referring to the common sentiment that "I know that the pressure of an imminent trial date sometimes has more influence over parties' decision to settle than any other factor")).

124. Again, phased discovery works. See Section II.1 supra and accompanying notes.

125. Parkinson's Law, DicTIONARY.COM, http://dictionary.reference.com/browse/parkinson-s-law (last visited Dec. 22, 2015).

126. Susan Saab Fortney, The Billable Hours Derby: Empirical Data on the Problems and Pressure Points, 33 Fordham URB. L.J. 171, 180-81 (2005); Steven J. Harper, The Tyranny of the Billable Hour, N.Y. Times, Mar. 28, 2013, http://www.nytimes.com/2013/03/29/opinion/the-case-against-the-law-firm-billablehour.html. 
say that there is an economic incentive for a lawyer to spend just as much time as practicable — but not too much —on any given task, matter, or client. ${ }^{127}$ Or as put more fully:

Under a law firm budget based upon billable hours, the best way to increase revenue is either to increase the billing rate or increase the number of hours billed. As competition among law firms has increased over the years, the ability to raise rates has depended largely upon the economy. The classic supply-and-demand model dictates that raising rates far above what is generally charged in the marketplace will reduce demand for services by that practitioner. With rate increases limited by such economic influences, law firms desiring to increase their revenues resort to increasing the number of hours billed. The result of increasing the number of hours billed, however, heightens ethical dilemmas for the profession. ${ }^{128}$

One gets the idea, if politely put. This expansion of work may not be entirely the practice of dishonest lawyers; uninformed, stressed out lawyers may participate as well. ${ }^{129}$

That is, however, the more salacious way to present this issue. The more mundane way involves accounting for "catch-up" time. That is to say, billable legal work in which an attorney reacquaints herself with the facts of a case and/or catches up a colleague, temporary replacement, or permanent replacement. ${ }^{130}$ Longer running cases mean more "catch-up time," which is inefficient. ${ }^{131}$ And if under a phasing scheme cases contain the same amount of discovery, just spread out over more time, the cost criticism holds some water.

Ultimately the frustration inherent in this particular issue is one that expands beyond phasing, beyond proportionality, and in a sense beyond

127. Katherine L. Brown \& Kristin A. Mendoza, Ending the Tyranny of the Billable Hour: A Mandate for Change for the 21st Century Law Firm, 51 N.H. B.J. 66, 67 (2010).

128. Id.

129. Christine Parker \& David Ruschena, The Pressures of Billable Hours: Lessons from a Survey of Billing Practices Inside Law Firms, 9 U. ST. Thomas L.J. 619, 624 n.31 (2011) (citing Jesse Nelman, A Little Trust Can Go a Long Way Toward Saving the Billable Hour, 23 GEO. J. Legal ETHICS 717, 722 (2010) ("[A]busive billing may actually be the result of both billing ignorance and poor billing judgment, which are sustained by an environmental pressure for lawyers to conform to the unethical billing practices of their colleagues. Put simply, lawyers may not know the practices they employ are unethical.")).

130. It should be noted that phased discovery may well be unfairly harsh to third parties, given that they generally are involved in cases due to matters outside of their control and stand to gain little from the exercise of responding to subpoenas. See Amy Pomerantz Nickerson, Coercive Discovery and the First Amendment: Toward a Heightened Discoverability Standard, 57 UCLA L. REv. 841, 882 (2010) (noting that "in many cases the third party will often have little connection to the underlying action"). Therefore it may be prudent to not phase third-party discovery, allowing third parties in some instances to do one fell swoop of a collection rather than be pulled into a case on numerous occasions.

131. See, e.g., The Washington Economics Group, Inc., The Economic Impacts of Delays in Civil Trials in Florida's State Courts Due to Under-Funding, Fla. B. Ass'N WeBsite, Feb. 9, 2009, http:/www.floridabar.org/TFB/TFBResources.nsf/Attachments/1C1C563F8CAFFC2C8525 753E005573FF/\$FILE/WashingtonGroup.pdf. 
discovery. This problem can be recast as being more about the modern efficacy of a billable hour system of potentially unlimited expense and revenue as the standard means by which clients pay for litigation. Such a system will inherently lend itself to use by good and bad actors, as well as those in between. ${ }^{132}$ And the billable hour system, while certainly trending down in popularity, will not disappear overnight. ${ }^{133}$ While it is certainly a "dodge" to conclude that Parkinson's Law is a billable hour problem and not a phased discovery problem, it is certainly worth consideration as a mitigating factor. Phased discovery does work better in a system with spending limits. ${ }^{134}$

Lastly, this is a problem mitigated once again by the whole purpose of phased discovery; phased discovery should mean less discovery, in which case costs ought to be lower. If a phased discovery case takes longer for a period of three phases with ten depositions and 100,000 produced documents, at which point it settles with some discovery still outstanding, that case will likely still be cheaper than the same case in a shorter one-phase regime with twenty depositions and 200,000 documents.

\section{D. "A Dishonest Litigant Could Misuse Phased Discovery"}

Discovery misconduct is an unfortunate byproduct of a legal system so large and complicated that it must rely on the unsupervised cooperation of adversaries. It will not go away no matter what the rules are or become.

That being said, it is worth examining whether phased discovery makes discovery misconduct more likely, which would be a consideration in its effectiveness. The types of discovery misconduct generally are serving unnecessary discovery, failing to cooperate in scheduling or administering discovery, failing to respond to discovery altogether, and withholding or concealing key evidence. ${ }^{135}$ Motives for discovery misconduct run the gamut. A bad lawyer plays fast and loose with discovery for many reasons, including

132. See Brown \& Mendoza, supra note 127, at 67; Douglas McCollam, The Billable Hour: Are Its Days Numbered?, THE AM. LAw., Nov. 28, 2005, http://www.americanlawyer.com/id=900005441810/The-Billable-Hour-Are-Its-DaysNumbered?slreturn $=20160408203026$.

133. See Paul M. Barret, How Billable Hours Changes the Legal Professon, Bloomberg BusinessweeK, Dec. 4, 2014, http://www.bloomberg.com/news/articles/201412-04/how-billable-hours-changed-the-legal-profession, (Explaining that the billable hour remains popular despite common distaste because "[i]t gives clients some basis for auditing how they're being billed, and it rewards richly those attorneys who find ways to keep the meter running.").

134. Indeed, phased discovery works well within one commentator's discovery cost solution of assigning a "litigation budget" or "cap" to spending in a litigation. See Tidmarsh, supra note 3 .

135. See, e.g., David A. Grenardo, Tales from the Abyss: What Does it Take to Get Disbarred These Days? (ABA Section of Litigation Joint Committees' CLE Seminar, Jan. 19-21, 2012), http://ssrn.com/abstract=2114594] (2012), Social Sciences Research Network 2114594 
(but by no means limited to) because his case is bad; ${ }^{136}$ because he is too busy to effectively participate in the matter; because he is a jerk; or because his client demands it. ${ }^{137}$ Many techniques and motives act directly or collaterally as means to delay a lawsuit and make it more costly for an opponent, a nasty business that makes the lawsuit more costly for the court as well.

Since the result of phased discovery may mean elongated discovery, but of a lesser scope, it does seem as if potential misconduct is an issue. First, the bad actor will almost certainly argue for the largest possible discovery scope, regardless of propriety. More discovery equals more money spent. The increased emphasis on proportionality in the 2015 amendments brings the discussion of proportionality out of the parties' initial conference, where this foolishness would first surface, and puts it before a judge, where this foolishness can be curtailed. ${ }^{138}$ Phased discovery preserves this additional oversight and enhances it by requiring the parties and judge to agree on even more aspects of discovery.

In a phased system the parties and the judge are not just agreeing on the outer boundaries of what is discoverable. They are agreeing on the identity of the most important information to be discovered and the method of obtaining that information at the lowest possible cost. Foolishness in the face of this process will be more difficult to sustain than it was in $2014 .{ }^{139}$

\section{E. "Phased Discovery Will Force a Single Witness to Endure Multiple Depositions"}

It is likely that a multi-phased discovery process would result in the redeposition of key witnesses. "Non-overlapping" is key, as Rule 26(b)(1) prohibits discovery that is "unreasonably cumulative or duplicative."

Although there are no specific limitations on the number of times a person can be deposed, courts tend not to favor repeat depositions absent a compelling reason to order them. ${ }^{140}$ Such compelling reasons usually involve newly

136. As Edward Bennett Williams is said to have said, "A continuance is the same thing as an acquittal, it just doesn't last as long." See, e.g., Elaine McCardle, HLS Negotiation Workshop Hosted Robert Barnett, and Jack and Suzy Welch, HARV. L. TODAY (Mar. 27, 2009), http://today.law.harvard.edu/hls-negotiation-workshop-hosted-robert-barnett-andjack-and-suzy-welch.

137. See Grenardo, supra note 135.

138. Indeed, that is exactly what the Chief Justice would like to see happen. See ROBERTS 2015 REPORT, supra note 41, at 7 ("The amended rules accordingly emphasize the crucial role of federal judges in engaging in early and effective case management.").

139. See Girard \& Espinosa, supra note 17; Michael Murphy, Proposed Federal Rules Will Discourage Document Dumps, Legal InTELligencer (Dec. 31, 2013), http://www.thelegalintelligencer.com/id=1202635329141/Proposed-Federal-Rules-WillDiscourage-Document-Dumps?slreturn=20151108212029.

140. Lakewood Eng'g \& Mfg. Co. v. Lasko Products, Inc., No. 01 C 7867, 2003 WL $1220254 * 8$ (N.D. Ill. Mar. 14, 2003) (finding that the court is "generally opposed to 
discovered or unreasonably withheld evidence. ${ }^{141}$

In a phased discovery model, however, re-depositions could occur without newly discovered or withheld evidence. Rather, they would be a necessary factgathering mechanism in cases where the discovery phases tracked key areas of the parties' legal theories, such as a liability phase one versus a damages phase two.

Some courts have concluded that the hardship of re-deposition, especially for key witnesses, is not so great as to make it anathematic to discovery. ${ }^{142}$ Nevertheless, a re-deposition in phased discovery is certainly a possibility, and the difficult or expensive availability of a witness should be a factor in setting the scope of each phase.

\section{F. "Phased Discovery Will Bring About Serial Summary Judgment Motions"}

Particularly in instances in which discovery phases track the legal cornerstones of a complaint, it is easy to see a situation in which an aggressive litigant would take several "cracks" at summary judgment.

For example, if a case for breach of contract were split into phases that tracked the elements of a breach of contract claim, with the first phase dedicated to evidence of a contract, and so forth, it is possible that a wily defendant will make serial motions for summary judgment after every phase in an effort to: (a) drive up costs for other parties and (b) take every opportunity to exit the case.

The Federal Rules do not preclude serial summary judgment motions, though judges discourage them. ${ }^{143}$ A trial court has discretion over how such motions can be brought. Therefore, judges can hedge against this situation simply by choosing not to consider dispositive motions until discovery is fully complete, and suggesting (as some already do) that serial dispositive motions are disfavored. ${ }^{144}$

redeposing witnesses absent a clear showing of substantial need by the movant"); Graebner v. James River Corp., 130 F.R.D. 440, 441 (N.D. Cal. 1989).

141. Graebner, 130 F.R.D. at 441.

142. See, e.g., Armstrong v. Hussman Corp., 163 F.R.D. 299 (E.D. Mo. 1995) (ordering re-deposition of witnesses).

143. See, e.g., Noble Roman's, Inc. v. Hattenhauer Distrib. Co., No. 1:14-cv-1734WTL-DML, 2015 WL 4523514, at*1-2 (S.D. Ind. July 27, 2015) (admonishing litigant for bringing multiple summary judgment motions).

144. For example, the Southern District of Indiana has amended its Uniform Case Management Plan to include the following language regarding summary judgment motions: "[a]bsent leave of court, and for good cause shown, all issues raised on summary judgment under Fed. R. Civ. P. 56 must be raised by a party in a single motion." Uniform Case Management Plan, $7 \mathrm{http} / /$ www.insd.uscourts.gov/case-management-plans; see also, e.g., Order at 3, Cooper v. Shelby County (No. 07-2283 STAlcgc) (W.D. Tenn. June 11, 2010), http://www.gpo.gov/fdsys/pkg/USCOURTS-tnwd-2_07-cv-02283/pdf/USCOURTS-tnwd- 


\section{G. "Phased Discovery Is Only for Even-Footing 'Money' Cases”}

It is lastly true that phased discovery works better for some cases than others. This is so about any discovery system, of course, but it bears examining the "hard" cases and determining how phased discovery can be effective. The first such concern is of "information imbalance" or "information asymmetry." 145

Information asymmetry creates a scenario in which one party possesses all of the information necessary to set the proportions of discovery and the reasonable scope of each phase. The other party can only guess at an appropriate scope based on much more limited information. ${ }^{146}$ Therefore one party can use that knowledge to drive the scope of discovery by making a case that the most helpful evidence to its legal theories be developed first (or last) depending on its tactical needs. A defendant, for example, with all of the evidence in its possession, might attempt to fashion phases of discovery so that the most helpful exculpatory evidence be examined first, allowing it to gain leverage in ongoing settlement discussions.

Judges can alleviate the potential gamesmanship by heeding the rules' direction to focus on access to discovery and to take an information-possessing party's suggestion of phasing sequence with caution. Some judges may even wish to provide deference to the phases and scope proposed by the party without the information. Doing so could make the first phase of discovery an exercise to level the playing field with respect to information possession and allow both parties to examine record facts on equal footing, which would provide for more balanced settlement discussions. For example, under Judge Grimm's phasing regime he defines this first phase as a "base level" discovery "proportionate to the needs of the case, the burden and expense of which is borne by the producing party with the provision that any further discovery must be conditioned on a showing of good cause and an assessment of cost allocation." 147

Further, the Committee Notes caution against the trap of letting the amount in controversy, the most quantitative of all factors, become the dominant factor

2_07-cv-02283-5.pdf (stating that dispositive motions cannot be "endless").

145. This phenomenon is described in the committee notes to the 2015 Amendments: "The direction to consider the parties' relative access to relevant information adds new text to provide explicit focus on considerations already implicit in present Rule 26(b)(2)(C)(iii). Some cases involve what often is called "information asymmetry." One party - often an individual plaintiff - may have very little discoverable information." FED. R. CIV. P. 26 advisory committee's notes to 2015 amendments, at B-40.

146. See, e.g., Rodney A. Satterwhite \& Matthew J. Quatrara, Asymmetrical Warfare: The Cost of Electronic Discovery in Employment Litigation, 14 RicH. J.L. \& TECH. 9, 11 (2008).

147. Paul W. Grimm \& David S. Yellin, A Pragmatic Approach to Discovery Reform: How Small Changes Can Make a Big Difference in Civil Discovery, 64 S.C. L. ReV. 495, 511 (2013). 
in determining proportionality:

It also is important to repeat the caution that the monetary stakes are only one factor, to be balanced against other factors. The 1983 Committee Note recognized 'the significance of the substantive issues, as measured in philosophic, social, or institutional terms. Thus the rule recognizes that many cases in public policy spheres, such as employment practices, free speech, and other matters, may have importance far beyond the monetary amount involved.' Many other substantive areas also may involve litigation that seeks relatively small amounts of money, or no money at all, but that seeks to vindicate vitally important personal or public values. ${ }^{148}$

This sentiment reflects a change made in the 2015 amendments, where, after the public comment period, the proportionality standard's "amount in controversy" factor was moved to a secondary position behind "the importance of the issues at stake in the action." 149 A system of phased discovery places a greater emphasis on determining the most important discovery and examining it first. This decision-making process is the cornerstone of a proportionality analysis. In other words, the information discovery most likely to be "proportional" is also the information most likely to be discovered in the "first" or "early" phases. So it is prudent for judges and parties to be sensitive to using the right determinants. Using the "importance of the issues at stake" as a means to expand the initial phase of discovery is commonsensical.

Indeed, in cases with extremely important issues, phasing need not be employed. ${ }^{150}$ However, if it is to become a useful tool for discovery, it should be the norm, used in most cases, with "hard" cases as potential exceptions. Making phasing purely optional does little to change the status quo as it is today. After all, the current rules presently provide for phasing in any and every case.

\section{But Would It Take?: The Practical Resistance to Phasing}

It is difficult to ignore at this point that the reasons for phasing discovery are fairly straightforward and simple, taking little real estate in this article, yet the contemplated obstacles to its implementation are numerous, varied, and

148. FeD. R. Civ. P. 26 advisory committee's notes to 2015 amendments, at B-41-B-42.

149. See, e.g., Thomas Y. Allman, The 2015 Civil Rules Package As Transmitted to Congress, E-Discovery BloG, (June 15, 2015), http://www.theediscoveryblog.com/wpcontent/uploads/2014/10/2015SummaryofRulesPackage.pdf.

150. See Carroll, supra note 54, at 465 (discussing a fixed discovery budget as "an interesting concept, but a limited one, because it calls for a global proportionality analysis rather than a specific one. Where what is at stake is solely money and the maximum and minimum amounts can be easily quantified, pursuit of a discovery budget and limiting discovery based on that budget may well make sense and be appropriate. In a contract action, for example, where the maximum damages are $\$ 100,000$, that figure may well represent what is 'at stake' in the litigation. But such monetizing of what is 'at stake' is not so easy where the issue is not breach of contract but constitutional or statutory civil rights."). 
lengthy. Why is that? One side effect of phased discovery that will make it more difficult to implement is its efficiency; if it works the way it should, there should be fewer cases, cases should be shorter, and litigants should be spending less on lawyers and (in many cases) more on redress of grievances.

Something about that last sentence may have jumped out at many readers: the part about lawyers being paid less. That is the idea of proportionality in general and phased discovery in particular; as one can imagine, it is easier said than done when the principal drivers of implementation are doing so at the risk of their own bottom line. ${ }^{151}$

On the other hand, it is also useful to note once again that phasing is completely possible under the existing discovery rules and encouraged by the new rules. ${ }^{152}$ Yet it is not prevalent. Why not? Once again it seems overly= simplistic to accredit this circumstance to inertia, although inertia should not be ignored. Or rather, perhaps inertia should be more closely examined. Why is change so hard to come by in the legal industry?

A colloquial example with respect to the broader practice in electronic discovery may come to mind. Client asks a Lawyer why Lawyer has printed out electronic documents to review them, citing the inherent inefficiency in time and money for such an archaic practice. Lawyer responds that he has over thirty years of experience reviewing documents for trial on paper, following a certain process, which has produced exceptional results at a rate greater than mere chance would dictate. Lawyer presents his own metaphor to Client, asking Client to imagine a scenario in which Client was to undergo surgery. A surgeon is about to operate on Client - heart surgery — and gives Client a choice: a three-hour surgery at added cost, but using a method the surgeon knows by heart, or a two-hour surgery that is cheaper, but uses a method that the surgeon will be trying for the very first time. No patient, and no Client, would want to be the first test case, given the stakes. ${ }^{153}$

151. See Tidmarsh, supra note 3, at 910-11 (discussing how limiting discovery cost is not exactly in an unethical lawyer's best interest). There is something to be said, however, for more efficient and less expensive cases reducing a barrier to the courts for parties, especially those with lesser means. Less expensive court cases may end up meaning that more litigants file more cases, making for more fees for more lawyers. See Ray Brescia, Disrupting the Law: How Technology Can Help Bridge the Justice Gap, HufFInGTON Post TECH: THE BlOG (Nov. 3, 2014, 04:16 PM), http://www.huffingtonpost.com/raybrescia/disrupting-the-law-how-te_b_6093062.html; Michael Zuckerman, Is There Such a Thing as an Affordable Lawyer?, Atlantic (May 30, 2014), http://www.theatlantic.com/business/archive/2014/05/is-there-such-a-thing-as-an-affordablelawyer/371746.

152. See, e.g., Laura E. Ellsworth et al., Significant Changes to the Federal Rules of Civil Procedure Expected to Take Effect December 1, 2015: Practical Implications and What Litigators Need to Know, JONES DAY (Sept. 2015), http://www.jonesday.com/significant-changes-to-the-federal-rules-of-civil-procedureexpected-to-take-effect-december-1-12015-practical-implications-and-what-litigators-needto-know-09-25-2015.

153. Of course, "imagine I'm a doctor" is one of the most classic and popular fallacies 
Ultimately, the reasoning behind this illustration may be the underlying source of anticipated resistance to phasing, and also the explanation for its lack of prevalence. There is simply a resistance to trying a new method that may not work, when so much is (or at the very least, can be) at stake in litigation. No lawyer wants to explain to a client, nor a judge to litigants, that a new way of resolving a case did not work effectively. It is the fear of the "unknown unknown." $" 154$ The idea that a smoking-gun document could exist in some corner and never see the light of a trier of fact is one with a real grip on the minds of attorneys, even if the reality is that many smoking-gun documents are known to parties at the outset of litigation, and others are generally too potentially relevant to avoid discovery.

In this way the axiom "the perfect is the enemy of the good" comes to mind. "Perfect" discovery is not only simply unattainable given the fallible nature of human recollection, it is simply not economically feasible given the complexity of big data. Indeed, the resistance to phasing may look like the industry's similar resistance to technology assisted review, which went from science fiction to accepted methodology in roughly three years. ${ }^{155}$ Insistence on a perception of perfection through total completion comes at the expense of better systems, a point not lost on the judges adopting predictive coding. ${ }^{156}$ Opponents of machine-aided review refused to accept the hard data which clearly showed that TAR results in more effective and efficient document review. ${ }^{157}$ Over time - a brief amount of time - the hard data showed that predictive coding, while seemingly "inhuman," was faster, cheaper and more effective than human review. ${ }^{158}$

Here, phasing asks those similarly situated to accept a related idea: that human eyes cannot efficiently nor effectively lay upon all relevant materials in discovery, and that some potentially relevant information should be disregarded without human review. ${ }^{159}$ It follows that an insistence that the human eyes

committed by members of the bar. We can put that logical issue aside for the purposes of this example.

154. See STEYN, supra note 19 (quoting Donald Rumsfeld).

155. Rio Tinto PLC v. Vale S.A., 306 F.R.D. 125, 126-27 (S.D.N.Y. 2015) (discussing technology assisted review's road to acceptance, collecting cases, and stating that "[i]n the three years since Da Silva Moore, the case law has developed to the point that it is now black letter law that where the producing party wants to utilize TAR for document review, courts will permit it."). The Author of this Article remembers explaining TAR to a senior partner at a law firm in 2012, and receiving a response that could charitably be described as "extraordinarily suspicious." That same partner now routinely uses TAR.

156. Id.

157. Id.

158. Maura R. Grossman \& Gordon V. Cormack, Technology-Assisted Review in EDiscovery Can Be More Effective and More Efficient Than Exhaustive Manual Review, 17 Rich. J.L. \& TECH. 11, 43 (2011); Tim Stuhldreher, Predictive Coding Cuts Discovery Expenses, 28 CENT. PA. Bus. J. 19 (2012).

159. See, e.g., Laporte \& Redgrave, supra note 24 , at 22-23 ("[P]erfection in preserving all relevant electronically stored information is often impossible." (quoting Comm. on Rules 
review all potentially relevant material is counterproductive to the advancement of technology in litigation.

The anticipated resistance to phased discovery is that it is antithetical to the notion that a litigant has an unalienable right in discovery to examine every slip of paper or every byte of data that could potentially make his case. However, as seen herein, this notion: (1) was never the intent of the Federal Rules and is therefore not accurate; ${ }^{160}$ (2) is dangerously unworkable in the current era of Big Data; and (3) is a self-defeating notion. ${ }^{161}$

The adoption of the 2015 FRCP amendments is still in its infancy, so time will tell whether or not they achieve their desired effect — and the effect judges want them to have - of increasing the use of proportionality as a limitation to discovery. ${ }^{162}$ If, as judges say, the rules cannot overstate the importance of a proportionality analysis, why not require that analysis?

The current rules suggest such a result, but the lack of a requirement that judges use them allows for parties to set discovery-bilaterally or unilaterally - in the same old inefficient way.

Judicial involvement is necessary in 2016 and beyond. ${ }^{163}$ Requiring a

of Practice \& Procedure of the Judicial Conference of the U.S., Summary of the Report of the Judicial Conference Committee on Rules of Practice and Procedure, Rules App. B-61 at 41 (Sept. 2014))) (noting that "[i]t is now beyond dispute that gathering and reviewing all available potentially relevant electronic data is a practical impossibility in most cases.").

160. Id. at 22 (noting that proportionality was first introduced in a revised Rule 26(b)(1)(iii) in 1983 to "address the problems of discovery that is disproportionate to the individual lawsuit" by limiting discovery or "bring[ing] about more tailored discovery," and describing this event as a "watershed moment" in the development of the FRCP).

161. This notion is self-defeating because, as discussed herein, it is the rare case indeed in which a collection and fulsome examination of every single discoverable piece of information would be a cost effective method of resolving a dispute. Most, if not all, cases are not worth an examination of all discoverable information. See, e.g., Green, supra note 14.

162. For example, a panel of federal judges stated that "the importance of proportionality cannot be overstated in the Rules. The Rules already state that the Court must limit discovery if it determines that the burden or expense of discovery outweighs the benefit. So some definition for proportionality has been added. A new factor is 'the parties' relative access to information.' This clause was added to take into account asymmetrical discovery and information." Chuck Kellner, Georgetown eDiscovery Institute 2014 Update on Changes to FRCP, D4 Discovery (Nov. 20, 2014), http://d4discovery.com/discovermore/2014/11/georgetown-ediscovery-institute-2014-update-on-changes-tofrcp\#sthash.RL6t37oC.dpuf.

163. See Siriano v. Goodman Mfg. Co., No. 2:14-cv-1131, 2015 U.S. Dist. LEXIS 165040 , at $* 19$ (S.D. Ohio Dec. 9, 2015) (stating expressly that the new Rules prescribe "active judicial case management"); ROBERTS 2015 REPORT, supra note 41, at 9-10 ("The 2015 civil rules amendments are a major stride toward a better federal court system. But they will achieve the goal of Rule 1-'the just, speedy, and inexpensive determination of every action and proceeding' - only if the entire legal community, including the bench, bar, and legal academy, step up to the challenge of making real change. ... It will also require a genuine commitment, by judges and lawyers alike, to ensure that our legal culture reflects the values we all ultimately share."). 
system of phased discovery is a strong way to make sure that discovery is proportional to the needs of the case and that the court and the parties "secure the just, speedy, and inexpensive determination of every action and proceeding." 164

\section{CONCLUSION}

Phasing is a common, proven technique used by savvy attorneys as a means to cooperatively limit discovery in a case, saving time and money. Phasing is used routinely by influential jurists such as Judge Paul Grimm as a standard for discovery cases, bringing reduced costs and better economy of judicial resources. ${ }^{165}$ Such is the cooperation contemplated by, and even required by, the amendments to the 2015 rules. Practitioners should insist on phased discovery. Judges should require it.

164. FED. R. CIV. P. 1

165. See Grimm, Discovery Order, supra note 102 
[Vol. 4:2 